\title{
Türkiye Ölçme Araçları Dizininde Yer Alan Açımlayıcı Faktör Analizi Çalışmalarının Paralel Analiz Sonuçları İle Karşılaştırılması
}

\section{Comparison of Exploratory Factor Analysis Studies in Turkish Measurement Tools Index According to Parallel Analysis Results}

\author{
Ufuk AKBAŞ* (iD Ersoy KARABAY** (iD Merve YILDIRIM-SEHERYELi் ${ }^{* * *}$ (iD) \\ Ahmet AYAZ ${ }^{* * *}$ (iD) Özgür Osman DEMİR ${ }^{* * * * *}$ (D)
}

Received: 15 August 2018

Research Article

Accepted: 25 July 2019

\begin{abstract}
The purpose of this study is to investigate the number of extracted factors in exploratory factor analysis (EFA) studies which takes part in Turkish Measurement Tools Index (TMTI / TOAD) according to parallel analysis results. By the date the study had begun, 4440 studies were indexed in TMTI, 500 studies were selected by systematic sampling procedure among them and the number of full texts investigated is 451 . For these studies, values were coded by using a form which was developed by researchers such as sample size, number of items, rotation method. For 300 studies in which EFA was implied, some of them do not include information about sample size, number of items, minimum factor loading, number of factors, extracted variance. The most frequent extraction method is principal component analysis, and criterion for number of factors is eigenvalue greater than unity. For multifactor scales typical rotation, method is varimax. Amongst 67 EFA studies that could be compared to parallel analysis results, 52 overextraction and seven underextraction situation was detected. For seven studies, number of factors were accurate. Findings are discussed within existing literature and a checklist is recommended for the purpose of minimizing deficiencies in reporting EFA results.
\end{abstract}

Keywords: Turkish Measurement Tools Index, exploratory factor analysis, parallel analysis, number of factors.

ÖZ: Bu araştırmanın amacı, Türkiye Ölçme Araçları Dizininde (TOAD) yer alan ölçek geliştirme veya uyarlama çalışmalarında açımlayıcı faktör analizi (AFA) ile belirlenmiş olan faktör sayılarının paralel analiz sonuçlarına göre incelenmesidir. Araştırmanın başladığı tarih itibariyle TOAD'da yer alan 4440 çalışma arasından 500'ü sistematik örnekleme yöntemiyle seçilmiş ve bu araştırmalardan 451'inin tam metnine ulaşılabilmiştir. Tam metnine ulaşılabilen çalışmalardaki örneklem büyüklüğü, madde sayısı, eksen döndürme yöntemi gibi bilgiler araştırmacılar tarafından geliştirilen bir forma göre kodlanmıştır. İncelemeler sonucunda AFA gerçekleştirilen 300 araştırma raporunda örneklem büyüklüğ̈̈, madde sayısı, faktör yükü alt sınırı, faktör sayısı, açıllanan varyans oranı gibi bilgilere yer vermeyen çalışmaların bulunduğu görülmüştür. AFA'da en sık kullanılan faktör çıkarma yönteminin temel bileşenler analizi olduğu, özdeğerin 1'den büyük olmasının ise faktör sayısına karar vermede en sık kullanılan ölçüt olduğu tespit edilmiştir. Birden çok faktörün çıkarıldığ 1 durumlarda en sık kullanılan eksen döndürme tekniği ise varimax’tır. Paralel analiz sonuçları ile karşılaştırılabilen 67 AFA çalışmasından 52'sinde fazla, sekizinde eksik ve yedisinde doğru sayıda faktörün çıkarıldığı belirlenmiştir. Bulgular mevcut alanyazın kapsamında tartışılmış ve AFA'nın raporlaştırılmasındaki eksiklerin azaltılabilmesi amacıyla bir kontrol listesi önerilmiştir.

Anahtar kelimeler: Türkiye Ölçme Araçları Dizini, açımlayıcı faktör analizi, paralel analiz, faktör sayısı.

\footnotetext{
* Corresponding Author: Asst. Prof. Dr., Hasan Kalyoncu University, Gaziantep, Turkey, ufuk.akbas@hku.edu.tr, https://orcid.org/0000-0002-6122-154X

*** Asst. Prof. Dr., Hasan Kalyoncu University, Gaziantep, Turkey, ekarabay@gmail.com, https://orcid.org/00000002-9499-2009

**** Res. Asst., Hasan Kalyoncu University, Gaziantep, Turkey, yldrm.mrv.7806@gmail.com, https://orcid.org/00000002-1106-5358

Res. Asst., Hasan Kalyoncu University, Gaziantep, Turkey, ahmet.ayaz@hku.edu.tr, https://orcid.org/0000-00024081-2033

Res. Asst., Hasan Kalyoncu University, Gaziantep, Turkey, demirozgur02@gmail.com, https://orcid.org/00000002-5073-151X
}

\section{Citation Information}

Akbaş, U., Karabay, E., Yıldırım-Seheryeli, M., Ayaz, A., \& Demir, Ö. O. (2019). Türkiye Ölçme Araçları Dizininde yer alan açımlayıcı faktör analizi çalışmalarının paralel analiz sonuçları ile karşılaştırılması. Kuramsal Eğitimbilim Dergisi [Journal of Theoretical Educational Science], 12(3), 1095-1123. 


\section{Giriş}

Eğitimde ve psikolojide ilgilenilen özellikler genellikle doğrudan gözlenmeyen, gizil yapılardır. Bu gizil özellikler ile ilgili çalışmalarda da ilgili yapıların en az hata ile ve amaca uygun olarak ölçülmesi amaçlanmaktadır. İlgilenilen yapı doğrudan gözlenemediğinden bu yapının ne kadar hatasız ölçüldüğü de kesin olarak bilinememektedir. Bunun yerine yapının ne kadar az hata ile ölçüldüğüne dair kanıtlar sunulmaktadır (Kelecioğlu \& Göçer Şahin, 2014). Bu noktada, ölçme aracı ile elde edilen verilerin güvenirliğini ve geçerliğini sorgulamak, nesnel kanıtları ile sunmak ve bu özelliklerin artırılması için yapılması gereken çalışmalar hakkında diğer araştırmacıları bilgilendirmek ilgili ölçme aracı üzerinde çalışan her araştırmacının görevidir. Cronbach (1990) geçerliği, testi geliştiren ya da kullananların puanlara dayalı çıkarımlarını desteklemek amacıyla ilgili kanıtları toplaması süreci olarak tanımlamaktadır. Buradan, geçerliğe ilişkin incelemelerin bitmeyen bir süreci ifade ettiği anlaşılmaktadır.

Geçerliğe ilişkin farklı sınıflamalar yapılmakla beraber geleneksel olarak geçerlik türleri kapsamla bağıntılı, ölçütle bağıntılı ve yapıyla bağıntılı geçerlik olarak gruplanmaktadır (Amerikan Eğitim Araştırmaları Birliği, Amerikan Psikoloji Birliği, Eğitim Ölçümleri Uluslararası Konseyi, 1998). Cronbach ve Meehl (1955) ile Loevinger (1957) gibi araştırmacılar, geçerliğe ilişkin tüm incelemelerin temelde yapı geçerliği çatısı altında yer aldığını ifade etmişlerdir. Bu görüşe göre kapsam geçerliğine veya ölçüt bağıntılı geçerliğe yönelik çalışmaların tümü yapı geçerliğine kanıt bulma sürecinin parçalarıdır. Sireci (2007) bu görüşe, eğitsel amaçlar doğrultusunda kullanılan testler için kapsam geçerliğinin son derece önemli olduğunu vurgulayarak karş1 çıkmaktadır. Geçerliğin tanımı, nasıl sınıflandırılacağı veya hangi kanıtların ne şekilde yorumlanacağı ile ilgili tartışmalar da devam etmektedir. Burada kısaca değinilen ve geçerlik ile ilgili farklı görüşlerin kapsamlı bir şekilde tartışıldığı çalışmaların (Kane, 2001; Kelecioğlu \& Göçer Şahin, 2014; Lissitz \& Samuelsen, 2007; Loevinger, 1957; Messick, 1995) incelenmesi önerilmektedir.

Özel olarak, yapı geçerliğine ilişkin kanıtların elde edilmesi sürecinde faktör analizi, hipotez testleri, uzman görüşlerinin alınması, grup farklılıkları, cevaplayıcıların cevaplama süreçlerinin çalışılması, ölçüt puanları ile korelasyonun incelenmesi (Anastasi \& Urbina, 1997; Baykul, 2000; Crocker \& Algina, 2008; Kline, 2016) gibi incelemeler yapılabilmekle birlikte Costello ve Osborne (2005) ve Erkuş (2016), ölçek geliştirme sürecinin başında açımlayıcı faktör analitik tekniklerin mutlaka kullanılması gerektiğini belirtmektedir.

Açımlayıcı faktör analizi, aynı yapıyı ya da niteliği ölçen değişkenleri bir araya toplayarak, ölçmeyi az sayıda faktör ile açıklamayı amaçlayan bir istatistiksel tekniktir. Faktör analizi, bir faktörleştirme ya da ortak faktör adı verilen yeni kavramları (değişkenleri) ortaya çıkarma ya da maddelerin faktör yük değerlerini kullanarak kavramların işlevsel tanımlarını elde etme süreci olarak tanımlanmaktadır (Büyüköztürk, 2018). Faktör analizinde araştırmacının göz önünde bulundurması gereken bazı durumlar ve bu durumlara ilişkin farklı öneriler söz konusudur. Bu durumlar ve sunulan bazı öneriler Tablo 1'de özetlenmiştir. 
Tablo 1

Açımlayıcı Faktör Analizinde Dikkate Alınması Gereken Durumlar ve Öneriler

AFA'da dikkate alınması gereken durum

Örneklem büyüklüğü

Faktör çıkarma / faktörleştirme yöntemi

Eksen döndürme tekniği

Faktör yükü

Binişiklik / Çapraz yük veren maddeler

Faktör sayısı ölçütü
Alanyazında karşılaşılan bazı öneriler

Mutlak ölçüt: 50 çok zayıf, 100 zayıf, 200 yeterli, 300 iyi, 500 çok iyi, 1000 mükemmel (Comrey \& Lee, 1992)

Bağıl ölçütler: madde sayısı x 2 (Kline, 1994), madde sayısı x 10 (Nunnally, 1978), faktör sayıs1 x 20 (Arrindel \& Van der Ende, 1985)

Temel bileşenler analizi

Ortak faktör analizi: Temel faktörler / eksenler, en çok olabilirlik, imaj, kanonik vd.

Dik (varimax, quartimax, vd.)

Eğik (direct oblimin, promax, vd.)

.30 (Costello \& Osborn, 2005)

.32 (Tabachnick \& Fidell, 2013)

.40 (Pedhazur \& Schmelkin Pedhazur, 1991; Stevens, 2009)

.45 / .30 (Büyüköztürk, 2018)

.50 (Todman \& Dugard, 2007)

Diğer faktörlerdeki yükün en az iki katı (Hinkin, 1998)

Faktör yükleri arasında en az .20'lik farkın olması (Howard, 2016)

Faktör yükleri arasında en az .10'luk farkın olması (Büyüköztürk, 2018)

Aralarındaki farktan bağımsız olarak en az iki faktördeki faktör yükünün .50 ve üzeri olması (Costello \& Osborn, 2005)

1 'in (Guttman, 1954; Kaiser, 1960) veya .70'in üzerindeki özdeğerlerin dikkate alınması (Jolliffe, 1972)

MAP testi (Velicer, 1976)

Çizgi / Yamaç-Birikinti Grafiği (Cattell, 1966)

Paralel analiz (Horn, 1965)

Öngörülen faktör sayısı (Hair, Black, Babin, Anderson, \& Tatham, 2006)

İstenen açıklanan varyans oranı (Dancey \& Reidy, 2007);

Olabilirlik oranı testi, Akaike bilgi kriteri, Schwarz bilgi kriteri (Pearson, Mundfrom, \& Piccone, 2013)

Tablo 1'de görüldüğü üzere dikkate alınması gereken farklı durumlar ve bu durumlara yönelik çeşitli öneriler söz konusudur. Örneklem büyüklüğü için belirtilen örnekler incelendiğinde Comrey ve Lee'nin (1992) ölçme aracındaki madde sayısından bağımsız olarak mutlak ölçüte dayalı önerilerde bulunduğu; Kline (1994) ve Nunnally'nin (1978) ise madde sayısına dayalı bağıl ölçütler önerdiği görülmektedir. Arrindel ve Van der Ende (1985) ise madde sayısına bağlı önerilerin isabetli olmadığını 
ifade etmekte ve örneklem büyüklüğünün, çıkarılacak faktör sayısının 20 katı kadar olmasını önermektedir.

Farklı teknikler olmalarına rağmen temel bileşenler analizi (TBA), açımlayıcı faktör analizi (AFA) şeklinde adlandırılarak yaygın bir şekilde kullanılmaktadır. Temel bileşenler analizi, gözlenen değişkenlerdeki varyansın mümkün olduğunca korunarak değişkenlerin, daha az sayıda değişken kümesine (bileşen) indirgenmesi amaciyla kullanılmaya uygundur (Park, Dailey, \& Lemus, 2002). Temel bileşenler analizi ile faktör analizinin temel ortak noktası ise çok sayıda değişken içeren veri setlerini bileşen ya da faktör olarak adlandırılan daha az sayıda değişkene indirgemeleridir. Değişkenlere ait ortak faktör varyanslarının hesaplanmasında, temel bileşenler analizinde hata terimi ihmal edilirken, faktör analizinde ortak faktörlerce açıklanmayan hata varyansı modelde dikkate alınır (Büyüköztürk, 2018; Dancey \& Reidy, 2007). Bu ortak noktaya bağlı olarak da temel bileşenler analizi sonucunda elde edilen yapılar (bileşenler) sıklıkla faktör olarak adlandırılmaktadır. Anlatımda birliğin sağlanması amacıyla bu araştırmada da faktör ve bileşen arasında bir ayrıma gidilmemiş ve "faktör" ifadesinin kullanımı ve benzer şekilde TBA ve AFA için de AFA ifadesinin kullanımı tercih edilmiştir. Bu tekniklerin özellikleri, dayandıkları matematiksel hesaplamalar ve birbirleriyle karşılaştırılmaları bu çalışmanın odağında yer almadığı için daha fazla ayrıntıya girilmemiştir. Bu tekniklerin ayrıntıları için Gorsuch (1983), Muthen ve Muthen (2010), Tabachnick ve Fidell (2013) ve Stevens (2009) gibi kaynaklardan yararlanılabilir; burada sadece tekniklerin kullanım sıklıklarına ilişkin kısa bir bilginin verilmesi yeterli görülmüştür. Peterson (2000) ve Henson ve Roberts (2006) çalışmalarda en sık kullanılan faktör çıkarma yönteminin temel bileşenler analizi olduğunu ifade etmektedir. Ortak faktör analizi (common factor analysis) için en sık kullanılan yöntem ise temel eksenler faktör analizidir (Pedhazur \& Schmelkin Pedhazur, 1991; Thompson, 2004).

Faktörler çıkarıldıktan sonra, maddelerin bu faktörler üzerindeki yükleri hesaplanabilir. Genel olarak, bütün maddelerin en önemli faktör üzerindeki yükleri yüksek, diğer faktörler üzerindeki yükleri ise düşüktür. Bu durum, elde edilen sonuçları yorumlamayı zorlaştırmaktadır (Field, 2013). Kavramsal anlamlılığı sağlamak için elde edilen faktörlerin daha iyi yorum verebilecek şekilde yeni faktörlere çevrilmesi gerekmektedir. Diğer bir deyişle, elde edilen faktörler döndürülmektedir (Tavşancıl, 2002). Sadece bir faktörün çıkarıldığı durumlarda eksenlerin döndürülmesi mümkün değil iken, iki ya da daha fazla faktör için döndürme zorunludur (Thompson, 2004). Temel olarak, yeni faktörlerin birbirleriyle ilişkisiz olduğu dik (orthogonal) ve faktörlerin birbiriyle ilişkili olduğu eğik (oblique) döndürme olmak üzere iki tür döndürme işlemi vardır (Stevens, 2009). Döndürmenin dik ya da eğik yöntemlere dayalı olarak yapılması konusundaki karar, faktörlerin ilişkili ya da ilişkisiz olduğuna yönelik sağlam kuramsal gerekçelere ve aynı zamanda maddelerin döndürme öncesindeki durumlarına bakılarak verilmelidir (Field, 2013). Pedhazur ve Schmelkin Pedhazur (1991) eğik döndürme sonucunda faktörler arasındaki korelasyonların önemsiz olduğu durumlarda dik döndürme yöntemlerinin tercih edilebileceğini ifade etmektedir. Field (2013) ve Erkuş (2016) dik ve eğik döndürme yöntemleri ile elde edilen sonuçların karşılaştırılmasını önermektedir.

Bir madde ile faktör arasındaki korelasyon katsayısı faktör yükü olarak tanımlanmaktadır (Kline, 1994). Bu değerin yüksek olması istenen bir durum olmakla 
birlikte, faktör yükünün .50 civarında (Todman \& Dugard, 2007), en az .40 (Pedhazur \& Schmelkin Pedhazur, 1991; Stevens, 2009) veya .32 (Tabachnick \& Fidell, 2013) olması gerektiği yönünde önerilerle karşılaşılmaktadır. Büyüköztürk (2018) faktör yük değerinin .45 ya da daha yüksek olmasının seçim için iyi bir ölçü olduğunu ve uygulamada az sayıda madde için bu sınırın .30'a kadar indirilebileceğini ifade etmektedir. Alanyazın incelendiğinde ise maddenin ilgili faktöre az da olsa katkı yapması gibi çeşitli gerekçeler ile kabul edilebilir faktör yükünün .15'e kadar düşürüldügüü örneklere de (Cassidy, 2016) rastlanmaktadır.

Costello ve Osborn (2005) iki ya da daha çok faktörde .32'nin üzerinde yük veren maddeleri çapraz yük veren / binişik madde olarak tanımlamakta ve bu durumun maddelerin düşük nitelikte olmasına veya öngörülen faktör yapısının kusurlu olmasına bağlı olabileceğini belirtmektedir. Büyüköztürk (2018) çok faktörlü bir yapıda, birden çok faktörde yüksek yük değeri veren maddenin ölçekten çıkarılabileceğini ifade etmektedir. Analizin, binişik maddeler çıkarıldıktan sonra tekrarlanması sorunu çözebilmektedir. Fakat araştırmacının, bu tür tavizler ile veri bütünlüğünün nasıl değişim gösterdiğini dikkate alması gerekir.

Tablo 1'de değinilen durumların dışında, alanyazında faktör başına düşen madde sayısının en az üç olması gerektiği yönünde görüş birliğinin olduğu söylenebilir. Ding, Velicer ve Harlow (1995) daha az sayıda maddenin yer alması halinde model - veri uyumun sağlanması konusunda sorunların yaşandığını belirterek bir faktör altında en az üç maddenin bulundurulmasını önermektedir. Hinkin (1998) bir faktörde dört ile altı arasında madde bulunması gerektiğini, Stevens (2009) ise bir faktördeki madde sayısının azalması ile maddelerin birer faktör olarak karşımıza çıkmaya başlayacağını ve üçten az sayıda madde içeren faktörlerin birer "faktör" olarak adlandırılmasının uygun olmadığını belirtmektedir. Benzer şekilde Bollen (1989), Costello ve Osborn (2005) ve Zwick ve Velicer'e (1986) göre de bir örtük özelliğin en az üç göstergesi olmalıdır. Diğer taraftan, bir ölçeğin farklı faktörleri altında bir veya iki maddenin yer aldığı örnekler (Luzzo \& McDonald, 1996; akt. Dancey \& Reidy, 2007) ile de karşılaşılmaktadır.

Burada belirtilen durum ve önerilerin birbirinden bağımsız olmadığı ve bir bütün olarak değerlendirilmesi de önem arz etmektedir. Örneğin, Guadagnoli \& Velicer (1988) bir faktörde, faktör yükü .60'1n üzerinde olan en az dört madde bulunması halinde örneklem büyüklüğünden bağımsız olarak yorumlanabilir sonuçlara ulaş1labileceğini, faktör başına 10-12 madde düştüğü ve faktör yüklerinin .40 olduğu durumlarda örneklem büyüklügüün̈n en az 150 ve faktör başına düşen madde sayısı ve faktör yüklerinin düşük olduğu durumlarda ise örneklem büyüklüğünün en az 300 olması gerektiğini ifade etmektedir. Buna göre, verilecek kararların ilişkili olduğu veya birbirini etkileyebildiği açıkça anlaşılmaktadır. Örneğin, en düşük faktör yükü için belirlenecek sınır, bir faktör altında yer alacak madde sayısını ve bu durum da faktör sayısını değiştirebilmektedir. Bununla beraber, bir faktör altında az sayıda madde yer almasına rağmen bu faktör ilgili psikolojik yapının önemli bir bölümüne karşılık gelebilir ve bir faktörün bulundurduğu madde sayısına göre açıkladığı varyans oranı daha çok bilgi verebilir. Tek bir yaklaşımın veya ölçütün her zaman doğru olmadığı ve çeşitli deneme ve değerlendirmelerin yapılması gereken bu süreci Erkuş (2016) yapıyı "koklamak" şeklinde ifade etmektedir. Benzer şekilde Thompson (2004) en iyi sonuçların birden çok yönteme dayalı olarak elde edilebileceğini, Gorsuch (1983) ise 
farklı yöntemlerle elde edilen sonuçların tümünde ortak olan faktörlerin esas alınması gerektiğini belirtmektedir.

Açımlayıcı faktör analizinde çıkarılabilecek olası faktör sayısı, analize dâhil edilen toplam madde sayısı kadardır. Bu faktörlerin çoğu, çözüme anlamlı katkı sağlamadığı veya yorumlanabilir olmadığı için dişarıda bırakılır ve hata terimi olarak ele alınır. Açımlayıcı faktör analizinin amacının, veri setindeki varyansı az sayıda faktör ile açıklamak olduğu da göz önüne alındığında, doğru sayıda faktöre ulaşmanın son derece önemli olduğu anlaşılmaktadır (Henson \& Roberts, 2006).

Faktör sayısının gerekenden az olması, fazla olmasına göre daha ciddi bir sorun olarak görülmektedir (Fabrigar, Wegener, MacCallum, \& Strahan, 1999; Fava \& Velicer, 1996). Wood, Tataryn ve Gorsuch (1996), faktör sayısının çıkarılması gerekenden daha az olduğu (underextraction) durumlarda değişkenlerin, modeldeki mevcut faktörlerde hatalı yüklere sahip olacağını ve elde edilen faktörlerin yorumlanmasının zorlaşacağını ifade etmektedir. Comrey (1978) bu gibi durumların, faktörlerin birleşerek gerçek faktör yapısının bozulmasına yol açabileceğine vurgu yapmaktadır. Faktör sayısının çıkarılması gerekenden fazla olması (overextraction) halinde ise önemli faktörlere isabetli bir şekilde yine ulaşılacak fakat fazladan eklenen faktörler altında ya hiç madde bulunmayacak ya da az sayıda madde bulunacaktır. Böyle durumlarda, kuramsal değeri olmayan veya tartışılması zor faktörler ile karşılaşılabilir (Fava \& Velicer, 1992; Wood ve diğ., 1996). Kline (1994) faktör sayısının az olduğu durumlarda ikinci düzey faktörlerin ortaya çıkabileceğini, fazla olduğu durumlarda ise faktörlerde bölünmelerin ortaya çıkabileceğini; Comrey (1978) her iki durumdan da kaçınılması gerektiğini belirtmektedir.

Bu noktada cevaplanması gereken temel soru, "faktör sayısının kaç olduğudur". Bir araştırmacı faktör sayısını belirlerken, yapıda kaç faktörün bulunabileceğine ilişkin kavramsal çerçeveyi ve ampirik kanıtlara dayalı olarak savunulabilecek faktör sayısını birlikte değerlendirmelidir (Hair ve diğ., 2006). Faktör sayısının belirlenmesinde sıklıkla kullanılan ölçütler kısaca açıklanmıştır:

K1 Ölçütü: Her bir faktör için faktör yüklerinin karelerinin toplamı ilgili faktör tarafından açıklanan varyans oranını ifade etmektedir. Bu toplam varyans ilgili faktörün karakteristik kökü ya da özdeğeridir (Kline, 1994). Guttman (1954) önemli faktör sayısının belirlenmesi için farklı ölçütleri karşılaştırmalı bir şekilde incelemiş; Kaiser (1960) de bu çalışmayı ilerleterek özdeğerin birden büyük olmasını en uygun yöntem olarak önermiştir. Çıkarılması gereken faktör sayısının özdeğeri birden büyük olanların dikkate alınarak belirlenmesi, K1 ölçütü olarak adlandırılmaktadır.

Kaiser (1960) bu ölçütün genellikle, madde sayısının altıda biri ile üçte biri arasında faktör ürettiğini ve özdeğerin birden büyük olmasının, güvenirliğin pozitif değerler alabilmesi için gerek ve yeter şart olduğunu ifade etmektedir. Diğer taraftan, örneklem korelasyon matrisinden elde edilen ve özdeğerleri sirasıyla .99 ile 1.01 olan iki faktörün açıkladıkları varyans oranı birbirine çok yakın iken K1 ölçütüne göre bu faktörlerden biri dışarıda bırakılacaktır ve her iki durumun da savunulması güçtür (Howard, 2016). Jolliffee (1972) faktör sayısının belirlenmesinde kullanılabilecek farklı yöntemleri yapay veri setleri üzerinden karşılaştırılmış ve özdeğerlerin büyük bir kısmının .60 - 1.40 aralığında değiștiği durumlarda faktör sayısının .70'in üzerindeki özdeğerleri dikkate alınarak belirlenebileceğini ifade etmiştir. $\mathrm{Bu}$ önerinin, negatif 
güvenirlik değerlerinin elde edilmesi ve gerekenden fazla faktörü ortaya çıkarması gibi sorunlar yaratabileceği dikkate alınmalıdır.

Çizgi / Yamaç-Birikinti Grafiği: Cattell (1966) tarafından önerilen grafiğin dikey ekseni özdeğerleri, yatay ekseni ise faktörleri temsil etmektedir. Özdeğerlerin grafik üzerinde belirtilmesi göreceli önemlerinin görünür bir hal almasını sağlamaktadır (Field, 2013). Grafik üzerinde özdeğerlere, büyüklüklerine göre siralı bir şekilde verildiği için de önce önemli faktörler, grafiğin sonraki kısımlarında ise önemsiz faktörler yer almaktadır. Çıkarılacak faktör sayısı, çizginin düşüşü bırakıp durağanlaştığı noktaya göre belirlenir (Gorsuch, 2003). Burada yatay çizgiler faktörlerin getirdikleri ek varyansların katkılarının birbirine yakın olduğunu gösterir. $\mathrm{Bu}$ da o faktörlerden birinin alınması durumunda diğerlerinin de alınmasını gerektirir, çünkü varyansa getirilen katk1 hemen hemen aynıdır (Büyüköztürk, 2018). Çizgi grafiğinin faktör sayısına karar vermede kullanılması, kesin bir kesme noktasının belirlenmesinde güçlüklerin yaşanabilmesi açısından eleştirilmektedir (Howard, 2016). Crawford ve Koopman (1979) bu yöntemin güvenirliğinin özellikle deneyimsiz araştırmacılar için oldukça düşük olduğunu belirtmektedir.

Minimum Average Partial (MAP) Testi: Velicer (1976) tarafından geliştirilen MAP testinde çıkarılan her bir faktörden sonra kısmi korelasyonların karelerinin ortalaması yeniden hesaplanmaktadır. Kısmi korelasyonların karelerinin ortalaması, hata matrisinin birim matrise en yakın olduğu noktada minimum değerini almakta ve bu noktadan sonra tekrar artış göstermektedir. Faktör sayısı, bu değerin en küçük olduğu noktaya göre belirlenmektedir. (Zwick \& Velicer, 1984). O'Connor (2000) orijinal korelasyon matrisinden hesaplanan ortalama değerin, "k-1" adımda çıkarılan ortalama değerlerin tümünden küçük olması halinde faktör çıkarılmaması gerektiğini belirtmektedir.

Paralel Analiz (PA): Horn (1965) evren düzeyinde, ilişkisiz değişkenlere ait korelasyon matrisinin tüm özdeğerlerinin 1 olacağını ve öte yandan rastgele değerler içeren bir veri seti üzerinden elde edilen 1'den büyük özdeğer sayısının beklenen değerinin, madde sayısının yarısı olduğunu ifade etmektedir. Özdeğerlerin birden ne kadar büyük olacağı da örneklem büyüklüğü ile ilişkilidir. Paralel analizde, gerçek veriye ait korelasyon matrisinin özdeğerleri ile aynı sayıda satır-sütundan oluşan ve rastgele değerler içeren veri setlerinin korelasyon matrislerinin özdeğerleri karşılaştırılmaktadır. Buna göre, gerçek verilerden elde edilen özdeğerlerin, rastgele (random) verilerden elde edilenlerden büyük olduğu noktaya kadar faktör çıkarılmalıdır. K1 ölçütüne benzer şekilde paralel analiz de gerçek veri setinden elde edilen özdeğerler ile paralel analizden bulunan özdeğerler arasındaki farkın çok küçük olduğu durumlarda hatalara yol açabileceği noktasında eleştirilmektedir (Howard, 2016). Paralel analizin fazla faktör üretebileceği ve karşılaştırmalarda ortalama özdeğer yerine \%95 veya \%99'luk güven aralığına karşılık gelen değerin dikkate alınabileceği belirtilmektedir (Buja \& Eyüboğlu, 1992; Glorfeld 1995; Wood, Akloubou Gnonsohou, \& Bowling, 2015). Crawford ve diğ. (2010) ise faktörlerin ilişkili olması durumunda güven aralığ yerine doğrudan özdeğer ortalamalarının dikkate alınmasının daha isabetli sonuç verdiğini belirlemiştir. Green, Levy, Thompson, Lu ve Lo (2012) ise PA'da \%95'lik özdeğerin kullanılmasının sadece ilk faktör için en etkili sonucu ürettiğini ifade etmektedir. Paralel analiz, SPSS ve SAS gibi sıklıkla yaygın kullanılan istatistik paket programlarında sözdizim dosyaları kullanılarak (Liu \& Rijmen, 2008; O’Connor, 2000), 
FACTOR gibi yazılımların ara yüzlerinden ilgili seçenek işaretlenerek (Lorenzo-Seva \& Ferrando, 2013) veya Monte Carlo PCA for Parallel Analysis (Watkins, 2000) gibi paket programlar ve web tabanlı uygulamalar (Patil, Singh, Mishra, \& Donavan, 2008) üzerinden kullanılan istatistik paket programından bağımsız bir şekilde gerçekleştirilebilmektedir. Pallant (2007) eğitim ve psikoloji alanlarında gerçekleştirilen çalışmaların makaleye dönüştürülmesi aşamasında paralel analiz sonuçlarına yer verilmesi gerektiğini ve Educational and Psychological Measurement ve Journal of Personality Assessment gibi dergilerin, bunu bir önkoşul olarak belirttiklerini ifade etmektedir.

Bunların dışında, istenen açıklanan varyans oranına ulaşmayı sağlayacak kadar faktörün çıkarılması (Dancey \& Reidy, 2007), analiz öncesinde öngörülen sayıda faktörün çıkarılması (Hair ve diğ., 2006), olabilirlik oranı testi, Akaike bilgi kriteri, Schwarz bilgi kriteri (Pearson ve diğ., 2013), Bartlett $\chi 2$ testi (Velicer, Eaton, \& Fava, 2000) ve en uygun koordinat ve ivme faktörü (Raiche, Walls, Magis, Riopel, \& Blais, 2013) gibi ölçütler hakkında daha detaylı bilgi için ilgili kaynaklardan yararlanılabilir.

AFA'da göz önüne alınan ölçütler ve analiz süreci ile bu süreç sonunda elde edilen bulguların raporlaştırılması bir tutarlılık ve bütünlük teşkil etmelidir. Burada öncelikle faktör sayısına karar vermede dikkate alınabilecek ölçütlerin temel alındığı araştırmalara ve ardından AFA sonuçlarının raporlaştırılması ile ilgili araştırmalara yer verilmiştir.

Zwick ve Velicer (1982) K1, MAP testi, Bartlett testi ve çizgi grafiğini farklı koşullar altında yapay veriler üzerinden karşılaştırmışlardır. Öznellik taşıdığı için eleştirilen çizgi grafiği için puanlayıcılar arası güvenirliğin oldukça yüksek olabileceği belirtilmiştir diğerlerine göre en isabetli sonuçları verdiği görülmüştür. MAP testi büyük ölçüde isabetli olmakla beraber madde ve faktör sayısının fazla faktör yüklerinin düşük olduğu durumlarda fazla faktör üretmiştir. Öte yandan, bu çalışmada tüm maddelerin ait olduğu faktörlerdeki yüklerinin eşit ve diğer maddelerdeki yükünün sıfır olacak şekilde ve faktörler altında yer alacak madde sayısı gibi değişkenlerin eşit tutulduğu da dikkate çekmektedir. Bu yönüyle çalışma, ideal bir faktör analizi sonucuna dayanmakta fakat uygulamada nadiren böyle sonuçlara ulaşılmaktadır. Araştırmacılar pek çok koşulda fazla faktör üreten K1 ölçütünün kullanımı için herhangi bir kanıta rastlamadıklarını ifade etmektedirler.

Zwick ve Velicer (1984) PA, MAP testi, çizgi grafiği, Bartlett testi ve K1 ölçütlerini yapay veri setleri üzerinden karşılaştırdıkları araştırmada örneklem büyüklüğü, madde sayısı, her bir faktöre düşen madde sayısı, faktörlerde eşit sayıda madde olup olmaması gibi koşulları manipüle etmişlerdir. Karşılaştırmaların sonucunda K1 ölçütünün olması gerekenden fazla sayıda faktör belirlediği ve Bartlett testi ile birlikte en düşük isabet oranına sahip olduğunu belirlemişlerdir. Çizgi grafiğinin tutarlı olmasa da isabetli sonuçlar üretebildiğini ve tek ölçüt olmaktan ziyade diğer ölçütleri destekleyici bir şekilde kullanılması gerektiğini belirtmişlerdir. Verilerin üretilmesi aşamasında belirlenen faktör sayıları için en isabetli sonuçlara PA ve MAP testi ile ulaşılmıştır.

Uyar (2012) tarafindan yapılan çalışmada ivme faktörü, K1, MAP testi ve PA ölçütlerinin faktör sayısını belirlemedeki doğruluk ve tutarlılığ 108 farklı koşul üzerinden yapay veri setleri kullanılarak karşılaştırılmıştır. Doğruluk oranı en yüksek 
olan ölçütün ivme faktörü, en tutarlı ölçütün ise PA olduğu ve K1 ölçütünün çoğu durumda fazla faktör ürettiği belirlenmiştir. MAP testinin doğru belirlediği faktör sayısının PA'dan daha az olduğu ve daha az sayıda faktör çıkarma eğiliminde olduğu görülmüştür. Faktör sayısının birden çok olduğu durumlarda genel olarak PA'nın doğruluk oranının MAP testinden daha yüksek olduğu ve örneklem büyüklüğü ile faktör yükü arttıkça PA'nın MAP testinden daha isabetli olduğu belirlenmiştir.

Ruscio ve Roche (2012) rastgele veriler yerine gözlenen korelasyon matrisine dayalı bir PA yöntemi önermişler ve dokuz ölçütü karşılaştırmışlardır. Örneklem büyüklügü, madde ve faktör sayısı, derece sayısı ve faktörler arasındaki korelasyonların farklı düzeyleri için önerdikleri yöntemin rastgele veriler kullanılarak gerçekleştirilen PA ile en iyi sonuçları verdiğini ifade etmişlerdir. Benzer şekilde, Pearson ve diğerleri (2013) faktör sayısını belirlemede dikkate alınabilecek on farklı ölçütü yapay veri setleri üzerinden çeşitli koşullar altında karşılaştırmışlar ve tüm koşullarda en isabetli sonuçların PA ile elde edildiğini ifade etmişlerdir.

Koçak, Çokluk ve Kayri (2016) K1, çizgi grafiği, PA ve MAP testini örneklem büyüklüğü ve madde sayısını manipüle ettikleri yapay veri setleri üzerinden karşılaştırmışlar ve PA ile MAP testinin isabetli ve birbirine benzer sonuçlar ürettiğini belirlemişlerdir. K1 ölçütü ve çizgi grafiği ile ise bu yöntemlere göre daha fazla sayıda faktör çıkarılmaktadır.

Yavuz ve Doğan (2015) tarafından yapılan çalışmada PISA 2006 verileri kullanılmış ve üç faktörlü olduğu bilinen bir yapı PA ve MAP testi ile incelenmiştir. Sonuçta her iki yöntem ile doğru sayıda faktör elde edilmiştir. Çokluk \& Koçak (2016) tarafından yapılan araştırmada PA ile K1 ve çizgi grafiği, Örgütsel Güven Ölçeği verileri üzerinden karşılaştırılmıştır. K1 ölçütünün fazla faktör ürettiği, PA ile ise olması gereken sayıda faktöre ulaşıldığ 1 ifade edilmiştir.

Yapay ve gerçek veriler üzerinden yürütülen bu araştırmalarda K1 ölçütü ile belirlenen faktör sayısının olması gerekenden fazla olduğu; PA ve MAP testinin benzer sonuçlar vermekle birlikte PA'nın daha isabetli olduğu yönünde bulgular ile karşılaşılmıştır. Bunlara ek olarak Comrey (1978) K1'in fazla sayıda faktör ürettiğini, Glorfeld (1995) ise büyük ölçüde isabetsiz olduğu halde K1 ölçütünün yaygın bir şekilde kullanıldığını belirtmektedir. Velicer ve diğ., (2000) öngörülen faktör sayısı, Bartlett testi, açıklanan varyans oranı ve K1 gibi ölçütlerin kullanılmamasını, çizgi grafiğinin ise tek başına kullanılmaması gerektiğini ifade etmektedir. Howard (2016) da benzer şekilde K1 yerine çizgi grafiği ile beraber PA, MAP testi veya her ikisinin birden kullanılması gerektiğini belirtmektedir. O'Connor (2000) ise MAP testinin genel olarak isabetli olduğunu fakat az sayıda faktör önerebildiğini ifade etmektedir. Bandalos ve Finney (2010) keşfedici bir teknik olan AFA ile farklı sonuçların elde edilebileceğini ve nihai kararın verilmesinde diğerlerine göre daha üstün olan PA gibi ölçütlerin, yanlılık gösterdiği bilinen $\mathrm{K} 1$ gibi ölçütlere tercih edilmesi gerektiğini ifade etmektedir.

Peterson (2000) faktör analizine yer veren 803 araştırmayı incelemiş ve en sik kullanılan yöntemin varimax döndürmeye dayalı TBA olduğunu belirlemiştir. İncelediği çalışmalarda analize dâhil edilen madde sayısı arttıkça faktör sayısının arttı̆̆ını fakat faktör yüklerinin düştüğünü görmüştür. Analiz sürecinde dikkate alınması gereken durumlara göre yaptığı incelemelerde ise ortalama faktör yükünün .32, açıklanan varyansın \%56.6 ve örneklem büyüklüğünün 398, ortanca madde sayısının 18 ve madde başına düşen ortalama kişi sayısının ise 14 olduğunu belirlemiştir. 
Henson ve Roberts (2006) tarafından yapılan benzer bir çalışmada eğitim ve psikoloji alanlarında dört dergide yer alan ve AFA'ya yer veren 60 makale incelenmiştir. Söz konusu çalışmalarda faktör yükü alt sınırının $.30-.50$, açıklanan varyans oranının ise \%16.7 - \%87.50 aralığında değiştiğini görmüşlerdir. Ortanca örneklem büyüklügü 267 iken madde başına düşen kişi sayısının ortancası 11, ortalaması ise 27 'dir. Faktör sayısına karar verilirken MAP testinden hiç yararlanılmazken çalışmaların \%7'sinde PA'ya yer verildiği, \%34'ünde ise tek bir ölçütten yararlanıldığı görülmüştür. Bunların haricinde bazı çalışmalarda faktör çıkarma yöntemi, örneklem büyüklüğü, eksen döndürme yöntemi, döndürme yöntemi olarak direct oblimin kullanıldığında da delta değeri gibi bazı bilgilerde eksiklerin olduğunu ifade etmektedirler.

Howard (2016) yedi dergideki 163 AFA çalışmasını incelemiş ve en sık karşılaşılan kombinasyonun TBA-varimax-K1 olduğunu belirlemiştir. Ortalaması 379 olan örneklem büyüklüğü için en sık karşılaşılan aralık 101 - 200'dür. Faktör sayıs1 ölçütü olarak çalışmaların \%52'sinde K1 ölçütü, \%8'inde ise PA sonuçları dikkate alınmış, \%35'inde ise herhangi bir ölçütten bahsedilmemiştir.

Izquierdo, Olea ve Abad (2014) 2011 ve 2012 yıllarında üç psikoloji dergisindeki 117 çalışmayı incelemişler ve önerilmeyen TBA-varimax-K1 kombinasyonunun en sik karşılaşılan durum olduğunu tespit etmişlerdir. İncelenen çalışmaların \%23'ünde faktör sayısının hangi ölçütlere göre belirlendiğinin, eksenlerin eğik döndürüldüğü çalışmaların \%64'ünde verilen matrisin örüntü mü yoksa yap1 matrisi mi olduğunun ve bu çalışmaların \%57'sinde de faktörler arası korelasyonların belirtilmediğini görmüşlerdir.

Patil ve diğ. (2008) inceledikleri 73 araştırma raporundan sadece altısında özdeğerlerin, madde sayısının ve örneklem büyüklügüünün belirtildiğini ve faktör sayısının belirlenmesinde K1 ve çizgi grafiği dışındaki ölçütlerden bahseden sadece iki çalışma ile karşılaştıklarını ifade etmişlerdir. Ayrıca 34 çalışmada faktör sayısının hangi ölçütlere göre belirlendiğine ilişkin herhangi bir bilginin yer almadığını tespit etmişlerdir. Yaptıkları karşılaştırmalarda, çalışmaların çoğunda rapor edilen faktör sayısının PA ile elde edilenden daha fazla olduğunu belirlemişlerdir.

Fabrigar ve diğ. (1999) 1991 - 1995 yılları arasında psikoloji alanındaki iki dergide yayımlanan çalışmaları incelemiş ve varimax döndürmeye dayalı TBA'nın en sık kullanılan yöntem olduğunu belirlemişlerdir. 217 çalışmanın 66'sında faktör sayısı için herhangi bir ölçütten bahsedilmezken, K1 ve çizgi grafiğinin yaygın kullanıldığ $v e$ sadece bir çalışmada PA'dan yararlanıldığı tespit edilmiştir. Araştırmacılar AFA bulgularının sunumunun ise genel olarak yetersiz olduğunu ifade etmektedirler.

Hayton, Allen ve Scarpello (2004) 1990 - 1999 yılları arasında yayımlanan 142 çalışmayı incelemiş ve \%25'inde sadece K1 ölçütünün esas alındığını, PA'dan yararlanan çalışma bulunmadığını ve çalışmaların çoğunda faktör sayısına karar verme ölçütünden bahsedilmediğini tespit etmişlerdir.

Franklin, Gibson, Robertson, Pohlman ve Fralish (1995) 1987-1993 y1lları arasında dört dergide AFA'ya yer veren 61 makaleye ulaşarak 50'sinde örneklem, madde sayısı ya da açıklanan varyans oranı gibi bilgilerin verildiğini; 29 makalede faktör sayısına karar verme ölçütünden bahsedilmediğini belirlemişlerdir. Bununla birlikte faktör sayısına karar vermede PA’nın kullanıldığı bir makaleye ulaşmışlardır. 
İlgili makalelerdeki AFA sonuçlarını PA ile karşılaştırdıklarında ise \%67'sinde fazla sayıda faktörün çıkarıldığını tespit etmişlerdir.

Türkiye'de yürütülen ölçek geliştirme / uyarlama çalışmalarında ve bu çalışmaların raporlaştırılmasında da burada bahsedilenlere benzer sorunların varlığ çeşitli araştırmalar ile ortaya konmuştur (Acar Güvendir \& Özer Özkan, 2015; Çüm \& Koç, 2013; Delice \& Ergene, 2015; Kaya Uyanık, Güler, Taşdelen Teker \& Demir, 2017; Şahin \& Boztunç Öztürk, 2018). Bu çalışmalarda genel olarak ölçek geliştirme veya uyarlama süreçleri incelenmiş; buradaki gibi açımlayıcı faktör analizine veya paralel analiz karşılaştırmasına odaklanılmamıştır. Bu noktada, ölçek geliştirme ve uyarlama çalışmaları kapsamında gerçekleştirilen AFA sonuçlarının nasıl raporlaştırıldığının ve paralel analiz sonuçları ile karşılaştırmalı bir şekilde incelenmesinin gerekli olduğu düşünülmüştür. Bu araştırmanın temel amac1, Türkiye'de AFA'ya yer verilen ölçek geliştirme veya uyarlama çalışmaları ile elde edilen faktör sayılarının paralel analiz sonuçları ile karşılaştırılmasıdır. $\mathrm{Bu}$ temel amaç doğrultusunda, Türkiye Ölçme Araçları Dizini (TÖAD / http://toad.edam.com.tr/) esas alınarak şu sorulara cevap aranmıştır:

a. TÖAD'da yer alan araştırmaların kaçında AFA yapılmıştır?

b. AFA yapılan çalışmalarda örneklem büyüklüğü, madde sayısı, kabul edilen en düşük faktör yükü, elde edilen faktör sayısı ve açıklanan toplam varyans oranına ilişkin betimsel istatistikler nasıldır?

c. AFA'da hangi faktör çıkarma tekniklerinden, faktör sayısına karar verme ölçütlerinden ve eksen döndürme teknikerlerinden yararlanılmaktadır?

d. AFA'da elde edilen özdeğerler, paralel analiz sonuçları ile karşılaştırıldığında nasıl bir durum ortaya çıkmaktadır?

\section{Yöntem}

$\mathrm{Bu}$ araştırma, geçmişte ya da halen var olan bir durumu var olduğu şekliyle betimlemeyi amaçladığı, araştırmaya konu olan olay, birey ya da nesne, kendi koşulları içinde ve olduğu gibi tanımlanmaya çalışıldığı için (Karasar, 1998) tarama modelinde betimsel bir araştırmadır.

\section{Verilerin Toplanması}

Türkiye Ölçme Araçları Dizini, her geçen gün büyümekte olan önemli bir bilgi kaynağıdır. Örneğin TÖAD’da, bu araştırmanın tasarlandığı 2018 Şubat ayında 4400, araştırmanın sonlandığı 2018 Haziran ayında 5873 ölçek dizinlenmekte ve yeni çalışmalar eklendikçe de bu sayı artmaktadır. Çeşitli ölçme araçlarını kapsayan Akın (2015), Kuzgun ve Bacanlı (2012) ve Öner (2006) gibi kaynaklar bulunmakla beraber; bu dizin üzerinden çok sayıda ölçeğe, bu ölçeklerle ilgili ayrıntılı bilgi ve dokümana rahatlıkla ulaşılabilmektedir.

Öte yandan, TÖAD’da yer alan ölçeklerin bir kısmına erişim sağlanamamakta, bir kısmıyla da aynı veya benzer adlarla tekrarlı kayıt şeklinde karşılaşılmaktadır. Dolayısıyla dizinde yer alan ölçeklerin sayısı hem tam olarak bilinememekte hem de giderek artmaktadır. Bu gibi durumlarda Erkuş (2013) sistematik örneklemenin uygun olacağını belirtmektedir. TÖAD'da yer alan ölçekleri örnekleyebilmek için her birinde 100'er ölçeğin bulunduğu 44 sayfadan (örn., http://toad.edam.com.tr/olcek?page=24) beşi (8-16-24-32 ve 40. sayfalar) seçilmiştir. 
Örnekleme giren çalışmaların yöntem ve bulgular bölümlerinde rapor edilen bilgiler, araştırmacılar tarafından geliştirilen bir form kullanılarak birleştirilmiştir. $\mathrm{Bu}$ formda, ilgili araştırmanın yayım tarihi, türü, hangi alanda yapıldığı ve benzeri bilgilere ek olarak AFA'da kaç faktör çıkarıldığı, madde sayısı ve açıklanan varyans oranının kaç olduğu gibi değişkenlere ilişkin kodlamaların nasıl yapılacağı belirlenmiştir. Form dört farklı araştırmacı tarafından rastgele seçilen 40 çalışma için denenmiş, tespit edilen eksiklere bağlı olarak gerekli düzenlemeler yapılarak son hali verilmiştir.

Örnekleme seçilen 500 çalışmadan 27'sinin, TÖAD veri tabanında tekrarlı kayıt şeklinde yer aldığı belirlenmiş ve tekrarlı çalışmalara sadece bir kez yer verilmiştir. Diğer bir deyişle, 473 farklı araştırma raporuna ulaşılmıştır. Bu araştırmaların bazılarında da birden çok ölçeğin geliştirildiği ya da birden çok AFA'nın yapıldığ görülmüş ve bunlar da birbirinden ayrı birer çalışma gibi değerlendirilmiştir. Bu süreç sonunda tam metnine erişim sağlanabilen toplam çalışma sayısı 451'dir. Benzer çalışmalarda (Acar Güvendir \& Özer Özkan, 2015; Çüm \& Koç, 2013; Delice \& Ergene, 2015; Kaya Uyanık ve diğ., 2017; Şahin \& Boztunç Öztürk, 2018) incelenen çalışma sayısının 50 ile 72 arasında değiştiği göz önüne alındığında, 451 çalışmanın incelendiği bu araştırmanın kapsamının oldukça geniş olduğu söylenebilir.

Araştırmanın başladığı tarihten sonra eklenen veya Türkiye'de gerçekleştirildiği halde TÖAD'da yer almayan çalışmalar araştırmanın kapsamı dışında tutulmuştur. İncelenen çalışmaların bir kısmında, bu araştırmanın odağında yer alan değişkenlere ait bilgilerin (örneğin, örneklem büyüklüğü) belirtilmediği görülmüştür. Bu durumun, söz konusu çalışmanın yer aldığı derginin sayfa ya da kelime sayısı sınırından bağımsız olduğu varsayılmıştır.

\section{Verilerin Analizi}

Örnekleme dâhil edilen çalışmalar incelendikten sonra elde edilen veriler ortak bir dosyada birleştirilmiştir. Veri dosyasında yer alan değişkenler tek tek filtrelenerek uç değer ya da kodlar arasında yer almayan değerler belirlenmiş ve veri girişinden kaynaklanan hataların telafi edilmesi sağlanmıştır. Farklı değişkenlere ait frekans tabloları ve çapraz tablolar oluşturulmuş; örneklem büyüklüğü, madde sayısı gibi değişkenlere ait betimsel istatistikler hesaplanmıştır.

Paralel analizde, birden çok korelasyon matrisine yer verilmesi halinde karşılaştırmalar ortalama özdeğerler üzerinden yapılmaktadır. $\mathrm{Bu}$ noktada kaç replikasyonun yapılacağına karar verilmesi gerekmektedir. Crawford ve Koopman (1973) sadece bir rastgele korelasyon matrisinden elde edilen özdeğerler ile 100 replikasyonun ortalaması alınarak elde edilen özdeğerler arasında manidar farkın olmadığını belirtmektedir. Longman, Cota, Holden ve Fekken (1991) ise 40 replikasyonun üç replikasyona göre daha isabetli olduğunu fakat aralarındaki farkın manidar olmadığını tespit etmiş ve buna bağlı olarak da birkaç replikasyonun yeterli olacağı önerilmişlerdir (akt. Velicer ve diğ., 2000). Bu araştırmada replikasyon sayısı 100 olarak belirlenmiştir.

AFA uygulayan ve bulgularında örneklem büyüklüğü, madde sayısı ve analiz sonucunda elde ettiği özdeğerleri raporlaştıran araştırmalardaki özdeğerler Watkins (2000) tarafından geliştirilen PA yazılımı kullanılarak elde edilen özdeğerler ile karşılaştırılmıştır. Çalışmalarda, çıkarılan faktör sayısına karşılık gelen özdeğerlerin paralel analiz ile elde edilenlerden küçük olduğu noktadan itibaren fazla sayıda faktörün 
çıkarıldığı, paralel analiz ile elde edilenden büyük olduğu halde çıkarılmayan faktörler için ise eksik faktör çıkarıldığı kabul edilmiştir. Madde sayısı, örneklem büyüklüğü veya tüm özdeğerlerin belirtilmediği çalışmalar için ise inceleme yapılamamıştır. Öte yandan, incelenen çalışmaların çoğunda analizler, veri setinden çeşitli sayıda madde çıkarılarak gerçekleştirilmiştir. Madde çıkarma işlemi matrisin özdeğerlerini değişecektir. Bu araştırmada, AFA sonuçlarına göre rapor edilen özdeğerler üzerinden karşılaştırma yapılabilmiştir. Dolayısıyla, AFA yapılırken ortaya çıkmış olabilecek farklı kombinasyonların incelenebilmesi mümkün olamamıştır.

\section{Bulgular}

$\mathrm{Bu}$ bölümde sırasıyla incelenen çalışmaların araştırma türüne ve alanına göre dağılımına, AFA'ya yer verilip verilmemesine, bazı değişkenlere ait betimsel istatistiklere, AFA'da verilen kararlara paralel analiz sonuçlarına göre karşılaştırma sonuçlarına yer verilmiştir. Tam metnine ulaşılabilen 451 çalışmanın araştırma alanı ve araştırma türüne ilişkin dağılımı Tablo 2’de verilmiştir.

Tablo 2

Incelenen Çalışmaların Araştırma Türü ve Alanına Göre Dă̆llımları

\begin{tabular}{lcccccc}
\hline \multirow{2}{*}{ Araştırma türü } & \multicolumn{5}{c}{ Alan } & \multirow{2}{*}{ Toplam } \\
\cline { 2 - 6 } & Eğitim & Sosyal & Sağlık & Spor & Diğer & \\
\hline Bildiri & $6(\% 1.3)$ & $3(\% 0.7)$ & - & - & - & $9(\% 2)$ \\
Makale & $152(\% 33.7)$ & $100(\% 22.2)$ & $16(\% 3.5)$ & $25(\% 5.5)$ & $1(0.2)$ & $294(\% 65.2)$ \\
Yüksek lisans tezi & $60(\% 13.3)$ & $22(\% 4.9)$ & $12(\% 2.7)$ & $3(\% 0.7)$ & $1(0.2)$ & $98(\% 21.7)$ \\
Doktora tezi & $22(\% 4.9)$ & $14(\% 3.1)$ & $2(\% 0.4)$ & $6(\% 1.3)$ & - & $44(\% 9.8)$ \\
Tipta uzmanlık & - & $2(\% 0.4)$ & $4(\% 0.9)$ & - & - & $6(\% 1.3)$ \\
\hline Toplam & $240(\% 53.2)$ & $141(\% 31.3)$ & $34(\% 7.5)$ & $34(\% 7.5)$ & $2(0.4)$ & $451(\% 100)$ \\
\hline
\end{tabular}

Tablo 2'de, incelenen çalışmaların yarısından fazlasının eğitim alanında yürütülmüş olduğu görülmektedir. Psikoloji, yönetim ve organizasyon, işletme gibi çeşitli sosyal bilim alanlarında yapılan çalışmaların oranı ise \%31'dir. İncelenen 451 çalışmanın yaklaşık \%65'i makale, \%22'si ise yüksek lisans tezidir. En düşük oranların ise mühendislik gibi alanlarda (diğer) yapılan çalışmalardan oluştuğu görülmektedir. İncelenen çalışmalar, 1993 ile 2018 yılları arasında yürütülmüştür. 
Söz konusu 451 çalışmadan 258'i (\%57) ölçek geliştirme, 193'ü (\%43) ölçek uyarlama çalışmasıdır. Tam metnine ulaşılabilen 451 çalışmanın ölçek geliştirme / uyarlama çalışması olma ve AFA içerip içermeme durumuna ilişkin dağılımı Tablo 3 'te verilmiştir.

Tablo 3

Tam Metnine Ulaşılabilen Çalışmaların Türü ve AFA'ya Yer Verip Vermeme Durumları

\begin{tabular}{llcl}
\hline \multirow{2}{*}{ Çalışma } & \multicolumn{2}{c}{ AFA } & Toplam \\
\cline { 2 - 3 } & Var & Yok & $193(\% 42.8)$ \\
\hline Ölçek uyarlama & $93(\% 20.6)$ & $100(\% 22.2)$ & $258(\% 57.2)$ \\
Ölçek geliştirme & $207(\% 45.9)$ & $51(\% 11.3)$ & $451(\% 100)$ \\
Toplam & $300(\% 66.5)$ & $151(\% 33.5)$ & \\
\hline
\end{tabular}

Tablo 3'te, ölçek uyarlama çalışmalarının 93'ünde AFA'ya yer verilirken 100'ünde AFA'ya yer verilmediği; 258 ölçek geliştirme çalışmasından 207'sinde AFA'ya yer verilirken 51 'inde yer verilmediği görülmektedir. AFA'ya yer vermeyen uyarlama çalışmalarının büyük bir kısmında temel istatistiksel yöntem, doğrulayıcı faktör analizi iken, AFA'ya yer vermeyen ölçek geliştirme çalışmalarında madde toplam korelasyonlarının incelenmesi veya uzman görüşüne dayalı geçerlik kanıtlarının elde edildiği görülmüştür. Tam metnine ulaşılabilen ve AFA'ya yer veren 300 çalışma için örneklem büyüklügü, madde sayısı ve kabul edilen minimum faktör yüküne ilişkin betimsel istatistikler Tablo 4'te verilmiştir.

Tablo 4

AFA'ya Yer Veren Çalışmalardaki Bazı Değişkenler İçin Betimsel İstatistikler

\begin{tabular}{lllllll}
\hline Değişken & Belirtmeyen & En k. & En b. & Mod & Ortanca & Ortalama \\
\hline Örneklem & 13 & 64 & 30170 & 95 & 340 & 508.38 \\
Analiz öncesi madde sayısı & 21 & 4 & 130 & 33 & 31 & 36.10 \\
Örneklem/madde oranı & 28 & 1.46 & 862 & 10 & 10.36 & 18.21 \\
Belirtilen faktör yükü alt sınırı & 95 & .15 & .60 & .30 & .32 & .36 \\
Faktör sayısı & 3 & 1 & 17 & 3 & 3 & 3.43 \\
Açılanan varyans oranı (\%) & 56 & 19.95 & 88.36 & 53.87 & 52.08 & 52.40 \\
Analiz sonrası madde sayısı & 17 & 4 & 111 & 20 & 22 & 25.71 \\
\hline
\end{tabular}

Tablo 4'ten, incelenen 300 çalışmanın bazılarında örneklem büyüklüğü, analiz öncesi ve sonrasına ilişkin madde sayısı, çıkarılan faktör sayısı ve açıklanan toplam varyans oranının belirtilmediği (ya da rapor edilen bulgulara dayalı çıkarımda bulunulamadığgi) anlaşılmaktadır. Örneklem büyüklüğü değişkenine ait betimsel istatistikler incelendiğinde en büyük değerin 30170 olduğu görülmektedir. İncelenen çalışmalar örneklem büyüklügüune göre sıralandığında, merkezi bir sınavın verileri üzerinden yürütülen bu araştırmadaki örneklem büyüklüğünü n=1948'lik bir çalışmanın 
izlediği ve bu çalışma çıkarıldığgnda ortalama örneklem büyüklügünün 404'e, örneklem büyüklügüunün madde sayısına oranı için elde edilen en büyük değerin de 88.54 'e indiği görülmüştür.

Söz konusu 300 çalışma faktör çıkarma tekniği, faktör sayısına karar verme ölçütü, eksen döndürme yöntemine göre incelenmiş ve elde edilen bulgular Tablo 5 'te verilmiştir.

Tablo 5

Incelenen Çalışmalar Iç̧in AFA'da Verilen Kararlar

\begin{tabular}{|c|c|c|c|c|c|}
\hline Faktör çıkarma & $\mathrm{f}(\%)$ & Ölçüt & $\mathrm{f}(\%)$ & Döndürme & $\mathrm{f}(\%)$ \\
\hline TBA & $212(\% 70.7)$ & $\mathrm{K} 1(K 2, f: 1)$ & $79(\% 26.3)$ & Varimax & $150(\% 61.7)$ \\
\hline Belirtilmemiş & $76(\% 25.3)$ & Belirtilmemiş & $92(\% 30.7)$ & Belirtmemiş & $68(\% 27.9)$ \\
\hline En çok olabilirlik & $6(\% 2)$ & $\mathrm{K} 1$, çizgi grafiği & $65(\% 21.7)$ & Direct oblimin & $10(\% 4.1)$ \\
\hline Temel eksenler & $3(\% 1)$ & Çizgi grafiği & $18(\% 6)$ & Promax & $9(\% 3.7)$ \\
\hline Diğer & $2(\% 0.7)$ & Kuram & $11(\% 3.7)$ & Denemeler & $3(\% 1.2)$ \\
\hline \multirow[t]{8}{*}{ Alfa } & $1(\% 0.3)$ & $\mathrm{K} 1$, kuram & $10(\% 3.3)$ & Equamax & $2(\% 0.8)$ \\
\hline & & Diğer & $8(\% 2.7)$ & Diğer & $1(\% 0.4)$ \\
\hline & & $\begin{array}{l}\text { K1, çizgi } \\
\text { grafiği, diğer }\end{array}$ & $8(\% 2.7)$ & & \\
\hline & & $\begin{array}{l}\text { K1, çizgi } \\
\text { grafiği, kuram }\end{array}$ & $4(\% 1.3)$ & & \\
\hline & & $\begin{array}{l}\text { K1, çizgi } \\
\text { grafiği, PA }\end{array}$ & $2(\% 0.7)$ & & \\
\hline & & $\begin{array}{l}\text { Çizgi grafiği, } \\
\text { kuram }\end{array}$ & $1(\% 0.3)$ & & \\
\hline & & $\begin{array}{l}\text { Çizgi grafiği, } \\
\text { diğer }\end{array}$ & $1(\% 0.3)$ & & \\
\hline & & $\begin{array}{l}\text { K1, çizgi } \\
\text { grafiği, PA, } \\
\text { MAP }\end{array}$ & $1(\% 0.3)$ & & \\
\hline Toplam & $300(\% 100)$ & Toplam & $300(\% 100)$ & Toplam & $243(\% 100)$ \\
\hline
\end{tabular}

${ }^{*}$ Bir faktörlü ölçekler dâhil edilmemiştir.

Tablo 5'te, en sık karşılaşılan faktör çıkarma yönteminin TBA olduğu, en çok olabilirlik ve temel eksenler yöntemlerine az sayıda da olsa yer verildiği görülmektedir. Çalışmaların yaklaşık \%25'inde faktör çıkarma yönteminin belirtilmediği tespit edilmiştir. Faktör sayısına karar vermede en sık dikkate alınan ölçütün K1 olduğu (\%26.3); ayrıca K1 ve çizgi grafiğinin birlikte dikkate alındığı durumlarla da sıklıkla karşılaşıldığı (\%21.7) görülmektedir. Ölçüt olarak sadece çizgi grafiğinin (\%6) ve sadece kuramsal çerçevenin (\%3.7) dikkate alındığı durumlarla göreceli olarak daha az karşılaşılmaktadır. İncelenen çalışmaların \%30.7'sinde ise faktör sayısının belirlenmesinde dikkate alınan ölçüt ya da ölçütlerden söz edilmediği belirlenmiştir. En sık karşılaşılan eksen döndürme yönteminin varimax (\%61.7) olduğu belirlenmiş ve çalışmaların \%27.9'unda ise eksenlerin hangi yönteme göre döndürüldüğüne ilişkin 
bilgiye rastlanmamıştır. Bir faktörün elde edildiği 57 çalışmanın altısında, eksenlerin dik (varimax) döndürüldüğü ifade edilmiştir.

AFA yapılan çalışmaların, paralel analiz ile karşılaştırılabilmesi için örneklem büyüklüğü, madde sayısı ve özdeğerlerin bilinmesi gerekmektedir. 300 çalışma içinde bu değerleri belirten çalışma sayısı 150 olup 83'ünde, sadece çıkarılan faktör sayısı kadar özdeğer bildirildiğinden karşılaştırma yapılamamıştır. Bu süreçte yapılan karşılaştırmalara ve verilen kararlara ilişkin birkaç örnek Tablo 6'da verilmiştir.

Tablo 6

Özdeğerlerin PA ile Karşılaştırılması ve Karara İlişkin Örnekler

\begin{tabular}{|c|c|c|c|c|c|c|c|c|c|c|c|c|}
\hline \multirow{2}{*}{ Örnek } & \multirow{2}{*}{$\mathrm{n}$} & \multirow{2}{*}{$\mathrm{k}$} & \multicolumn{5}{|c|}{ Çalışmadaki özdeğerler } & \multicolumn{4}{|c|}{ PA özdeğerler } & \multirow[t]{2}{*}{ Karar } \\
\hline & & & & $\lambda_{C \zeta 1}$ & $\lambda_{C \zeta 2}$ & $\lambda_{C \zeta 3}$ & $\lambda_{C 4}$ & $\lambda_{\mathrm{P} 1}$ & $\lambda_{\mathrm{P} 2}$ & $\lambda_{\mathrm{P} 3}$ & $\lambda_{\mathrm{P} 4}$ & \\
\hline 1 & 105 & 36 & 1 & 16.87 & 2.34 & $<1$ & $<1$ & 2.31 & 2.15 & 2.00 & 1.89 & Eksik (-1) \\
\hline 2 & 158 & 20 & 2 & 6.67 & 2.82 & 1.44 & 1.21 & 1.70 & 1.56 & 1.46 & 1.38 & Doğru \\
\hline 3 & 426 & 35 & 4 & 5.59 & 1.74 & 1.31 & 1.26 & 1.58 & 1.51 & 1.45 & 1.41 & Fazla $(+2)$ \\
\hline 4 & 241 & 31 & 2 & 9.91 & 2.83 & - & - & 1.74 & 1.64 & 1.56 & 1.50 & Belirsiz \\
\hline
\end{tabular}

Tablo 6'da $\mathrm{n}$ örneklem büyüklüğünü, $\mathrm{k}$ madde sayısını ve $\mathrm{F}$ çıkarılan faktör sayısını, $\lambda_{C ̧ 1}-\lambda_{C ̧ 4}$ ilgili çalışmada rapor edilen özdeğerleri, $\lambda_{P 1}-\lambda_{P 1}$ ise paralel analiz ile elde edilen özdeğerleri temsil etmektedir. Birinci örnekteki değerler incelendiğinde çalışmada bir faktör çıkarıldığı fakat ikinci özdeğerin (2.34) paralel analizle elde edilen ikinci özdeğerden (2.15) büyük olduğu görülmektedir. Bu gibi durumlarda eksik sayıda faktör çıkarıldığı yönünde karar verilmiştir. Bu örnek için eksik çıkarılan faktör sayısı birdir. İkinci örnek için rapor edilen özdeğerlerin ilk ikisi paralel analizle elde edilen değerlerden büyüktür. İki faktörün çıkarıldığı bu çalışmada faktör sayısı için verilen kararın doğru olduğu görülmektedir. Üçüncü örnekte, sadece ilk iki özdeğer paralel analizle elde edilenlerden büyük olmasına rağmen çıkarılan faktör sayısının dört olduğu görülmektedir. Dolayısıyla bu çalışma için fazladan iki faktörün çıkarıldığı yönünde karar verilmiştir. Dördüncü örnekte ise iki faktör çıkarılmış ve ilgili araştırmada sonraki özdeğerler verilmemiştir. Paralel analiz sonuçları ilk iki faktörü desteklese de sonraki faktörler için bir belirsizlik söz konusudur. Dördüncü örnek için karar verilen faktör sayısı doğru ya da eksik olabilir. Burada örnekleri verilenlere benzer şekilde gerçekleştirilen karşılaştırmalar sonucunda elde edilen bulgular Tablo 7'de verilmiştir. 
Tablo 7

Çıkarılan Faktör Sayılarının PA ile Karşılaştırılmasına İlişkin Sonuçlar

\begin{tabular}{|c|c|c|}
\hline Karar & & Frekans \\
\hline Belirsiz & & 83 \\
\hline Doğru & & 7 \\
\hline \multirow[t]{7}{*}{ Fazla } & & 52 \\
\hline & Paralel analiz sonuçlarına göre +1 faktör & 25 \\
\hline & Paralel analiz sonuçlarına göre +2 faktör & 16 \\
\hline & Paralel analiz sonuçlarına göre +3 faktör & 6 \\
\hline & Paralel analiz sonuçlarına göre +4 faktör & 3 \\
\hline & Paralel analiz sonuçlarına göre +5 faktör & 1 \\
\hline & Paralel analiz sonuçlarına göre +6 faktör & 1 \\
\hline \multirow[t]{4}{*}{ Eksik } & & 8 \\
\hline & Paralel analiz sonuçlarına göre -1 faktör & 6 \\
\hline & Paralel analiz sonuçlarına göre -2 faktör & 1 \\
\hline & Paralel analiz sonuçlarına göre -3 faktör & 1 \\
\hline Genel T & lam & 150 \\
\hline
\end{tabular}

Tablo 7'de, karşılaştırma yapılamayan 83 çalışma haricindeki 67 çalışmanın yedisinde doğru sayıda faktörün çıkarıldığ 1,52 'sinde fazla ve sekizinde ise eksik sayıda faktörün çıkarıldığı görülmektedir. Fazla çıkarılan faktör sayısının 1-6 arasında değiştiği ve fazladan bir faktörün en sık karşılaşılan durum olduğu; eksik faktör sayısının ise 1-3 arasında değiştiği ve bir faktörün eksik çıkarıldığı durumun en sık karşılaşılan durum olduğu görülmektedir.

\section{Sonuç ve Tartışma}

$\mathrm{Bu}$ araştırmada, Türkiye Ölçme Araçları Dizininde (TÖAD / http://toad.edam.com.tr/) yer alan ölçme araçları betimsel bir şekilde incelenmiş ve rapor edilen özdeğerler, paralel analiz ile karşılaştırılmıştır. Örnekleme seçilen 500 çalışmadan 451'inin tam metnine ulaşılabilmiştir. Bu çalışmalar içinde AFA'ya yer verilen 300 farklı çalışmanın bulunduğu tespit edilmiş ve bununla beraber, toplam 258 ölçek geliştirme çalışmasının 51'inde AFA'nın bulunmadığı belirlenmiştir. Bu durum, Costello ve Osborne (2005) ve Erkuş (2016) tarafından, ölçek geliştirme sürecinde AFA'ya mutlaka yer verilmesi gerektiği yönündeki ifadenin tam olarak karşılanmadığını ortaya koymaktadır.

AFA'ya yer veren 300 çalışmaya ilişkin betimsel istatistikler incelendiğinde, 64 ile 1948 (n=30170 olan bir çalışma hariç) arasında değişen büyüklüklerde örneklemler üzerinde çalışıldığ1 görülmüştür. Örneklem büyüklüğü için ortanca değer 340 iken aritmetik ortalama 404'tür (yine, $\mathrm{n}=30170$ olan çalışma hariç). Bu durum, incelenen çalışmalarda Comrey ve Lee (1992) tarafından örneklem büyüklüğü için önerilen mutlak ölçütlere genel olarak uyulduğunu fakat bazı çalışmaların AFA için küçük sayılabilecek örneklemlerde yürütüldüğünü ortaya koymaktadır. Öte yandan Türkiye'de gerçekleştirilen çalışmalardaki ortalama örneklem büyüklügünün Peterson (2000), 
Henson ve Roberts (2006) ve Howard'ın (2016) çalışmalarında belirlenenlere göre daha yüksek olduğu görülmüştür.

Bir maddeye ölçekte yer verilmesi için kabul edilen faktör yüklerinin .15'e kadar indirilebildiği görülmüştür. Bir maddenin faktör yükünün .15 düzeyinde olduğu durumlara örnekler (Cassidy, 2016) bulunmakla beraber, bu değerin Todman ve Dugard (2007), Pedhazur ve Schmelkin Pedhazur (1991) ve Stevens (2009) önerilen sinırları karşılamadığı görülmektedir. Kabul edilen faktör yüklerine ilişkin tepe değerin .30 ve ortalamanın .36 olması ise Tabachnick ve Fidell (2013) ve Büyüköztürk (2018) tarafindan genel olarak desteklenen bir durumdur. Bu bulgular, Peterson (2000), Henson ve Roberts (2006) tarafindan yürütülen çalışmaların bulguları ile de büyük benzerlik göstermektedir. Açıklanan varyans oranlarının \%19.95 - \%88.36 aralığında ve ortalamasının \%52.40; madde başına düşen ortalama kişi sayısının 18.21 ve tepe değerinin 10 olması Peterson (2000) ve Henson ve Roberts'ın (2006) ulaştıkları bulgular ve Nunnally'nin (1978) madde başına en az 10 kişinin düşmesi şeklindeki önerisi ile örtüşmektedir.

İncelenen çalışmalar arasında temel bileşenler analizine diğer faktör çıkarma tekniklerine göre baskın bir şekilde (\%71) rastlanması, benzer çalışmaların ortak bulgusu niteliğindedir (Peterson, 2000; Henson \& Roberts, 2006). Temel bileşenler analizi ile beraber faktör sayısına karar vermede en sık dikkate alınan ölçütün K1 ve en sık kullanılan eksen döndürme tekniğinin varimax olması da benzer araştırmaların (Glorfeld, 1995; Howard, 2016; Izquierdo ve diğ., 2014; Patil ve diğ., 2008; Fabrigar ve diğ., 1999; Hayton ve diğ., 2004) bulguları ile örtüşmektedir. Benzer şekilde, faktör sayısına karar verme ölçütü olarak yalnızca K1 ya da yalnızca çizgi grafiği, K1 ve beraberinde çizgi grafiğinin sıklıkla kullanılması; incelenen 300 çalışma içinde PA ve MAP testinden söz eden toplamda sadece üç çalışmanın bulunması gibi bulgular da bu çalışmalara benzer niteliktedir.

Bulguların buraya kadarki kısmı genel olarak değerlendirildiğinde örneklem büyüklüğü, faktör çıkarma tekniği, kabul edilen en küçük faktör yükü, faktör sayısına karar verme ölçütü gibi durumlara ilişkin belirlemelerde sorunların oldukça yaygın olduğu ve Türkiye’ye özgü olmadığı anlaşılmaktadır. Benzer araştırmalar ile örtüştüğü görülen diğer bir yaygın sorun, yürütülen araştırmalara ve istatistiksel analizlere ilişkin önemli bilgilere raporlarda yer verilmemesidir (Fabrigar ve diğ., 1999; Franklin ve diğ., 1995; Hayton ve diğ., 2004; Henson \& Roberts, 2006; Howard, 2016). Örneğin, örneklem büyüklüğünü belirtmeyen çalışma sayısı 13 (\%4), açılanan varyans oranını belirtmeyen çalışma sayısı ise 56'dır (\%19). Gerçekleştirilen analizin temel amacı, gözlenen değişkenlerdeki varyansın mümkün olduğunca korunmasıyla daha az sayıda değişkene ulaşmaktır (Büyüköztürk, 2018; Dancey \& Reidy, 2007; Park ve diğ., 2002). Fakat raporlarda, açıklanan varyans oranına yer verilmemesi Fabrigar ve diğ., (1999) ve Franklin ve diğerlerinin (1995) ulaştığı bulgulara benzer nitelikte olup önemli bir eksiklik olarak değerlendirilmektedir. $\mathrm{Bu}$ araştırmadaki bulguların literatürdeki benzerlerinden ayrıldığı nokta, analiz sonucunda ulaşılan faktör sayısının kaç olduğu yönünde yeterli bilgiye yer vermeyen çalışmalara da $(n=3)$ rastlanmış olmasıdır. Söz konusu üç çalışmadan birinde, faktör sayısının iki mi yoksa üç mü olduğu noktasında bir belirsizlik söz konusu iken, diğer ikisi ise faktör sayısı hakkında bilgi bulundurmamaktadır. Bu durum, AFA'nın amacı, raporlaştırılması ve ilgili raporun değerlendirilmesi gibi süreçlerde önemli eksiklerin olduğunu ortaya koymaktadır. 
$\mathrm{Bu}$ noktada, her ne kadar bu araştırmanın temel amaçları arasında olmasa da raporlaştırmada karşılaşılan diğer bazı sorunlardan kısaca bahsedilmesinin uygun olacağı düşünülmüştür. İncelenen 451 çalışmadan ikisinde, çalışmanın ölçek geliştirme çalışması olduğu belirtilmiş fakat daha önceden geliştirilmiş ölçeklerin uyarlandığ görülmüştür. AFA yapıldığı belirtilen bir çalışmada bu yönde herhangi bir bulguya yer verilmezken, bir çalışmada da bir faktörde .30 olarak belirlen en düşük faktör yükünün üzerinde yüke sahip madde bulunmadığı görülmüştür. Karşılaşılan bu gibi eksikler daha önce belirtilen çalışmalar ile de benzerlik göstermektedir.

Faktör sayısına karar vermede en sık kullanılan ölçütlerin yalnızca K1 ( $n=79$, \%26) ve K1 ile beraber çizgi grafiği ( $n=65, \% 22)$ olduğu görülmüştür. Bu durumun, söz konusu ölçütlerin SPSS gibi sıklıkla kullanılan istatistik paket programlarında öntanımlı (default) bir şekilde yer almasından kaynaklandığı düşünülmektedir. Öte yandan, faktör sayısı kararında herhangi bir ölçütten bahsetmeyen çalışmaların sayıca bunlardan daha fazla olması hem verilerin analizi hem de bulguların raporlaştırılması aşamasında bu konuya gereken önemin verilmediğini göstermektedir. Benzer şekilde, birden çok faktörün çıkarıldığı çalışmaların 68'inde (\%28) eksenlerin nasıl döndürüldüğüne ilişkin bir bilgi yer almamaktadır. Tek faktöre karar verilen altı çalışmada eksenlerin varimax döndürülmesi ise zaten matematiksel olarak mümkün değildir. Bu gibi durumlarda, istatistik paket programlarının çıktı dosyasında bir hata mesajıyla karşılaşılmaktadır.

İncelenenler arasında, paralel analiz ile karşılaştırmaların yapılmasına tam olarak imkân tanıyan çalışmaların sayısı 67'dir. Karşılaştırmalar sonucunda, çalışmaların 52'sinde fazla, sekizinde eksik ve yedisinde doğru sayıda faktörün çıkarıldığı görülmüştür. Fazla çıkarılan faktör sayılarının çoğunlukla 1-3 arasında olduğu ve altıya kadar çıktığı görülmüştür. Eksik sayıda faktörün çıkarıldığı sekiz çalışmada da sıklıkla bir faktörün eksik çıkarıldığı görülmüştür. Bu durum, Fabrigar ve diğ., (1992), Fava \& Velicer (1996), Wood ve diğ., (1996) ve Comrey (1978) gibi pek çok araştırmacının kaçınılması gerektiğini belirttikleri eksik ya da fazla sayıda faktörün, doğru sayıda faktöre göre daha sık karşılaşılan bir durum olduğunu ortaya koymaktadır. Patil ve diğ., (2008) ve Franklin ve diğ., (1995) tarafından yürütülen ve özdeğerlerin PA ile karşılaştırıldığı benzer araştırmalarda da çıkarılan faktör sayısının PA'ya göre daha fazla sayıda olduğu tespit edilmiştir.

\section{Öneriler}

$\mathrm{Bu}$ çalışmada incelemeler PA üzerinden sadece istatistiksel bir yaklaşımla gerçekleştirilmiş ise de AFA'nın bir anlamda sezgisel bir süreç olduğuna ve analiz sürecinde yapının kuramsal çerçevesinin de mutlaka göz önüne alınması gerektiğine dikkat edilmelidir. Çünkü yapıyı ortaya çıkarma ve ölçme, bir anlamda bir kuramın test edilmesidir (Erkuş, 2016). Faktör sayısına karar vermede birden çok yöntemin dikkate alınması daha isabetli sonuçların elde edilmesini sağlayabilir. Faktör sayısına karar verme aşamasında PA sonuçlarından yararlanılması noktasında araştırmacıların, kullanımı oldukça kolay ve ücretsiz yazılımlardan yararlanmaları önerilmektedir.

$\mathrm{Bu}$ araştırma, TÖAD'da yer alan diğer çalışmalar veya diğer istatistiksel analizler eklenerek genişletilebilir. Örneğin, doğrulayıcı faktör analizi sonucunda raporlaştırılan değerlerin veya yapılan yorumların incelendiği araştırmalar planlanabilir.

Ölçek geliştirme sürecinde, ölçekten madde çıkarmak zorunda kalınabilmektedir. İncelenen çalışmalarda, AFA öncesinde 36 civarında olan ortalama 
madde sayısının, analiz sonunda 26'ya düştüğü görülmüştür. $\mathrm{Bu}$ durum, AFA'da maddelerin yaklaşık olarak \%30'unun çıkarıldığını göstermektedir. Ölçek geliştirme çalışmalarının madde havuzu oluşturma aşamasında bu durumun dikkate alınması önemlidir.

Williams, Brown ve Onsman (2010) eğitim ve psikoloji alanlarındaki çalışmalara odaklanan dergilerin, faktör sayısına karar vermede çeşitli ölçütlerden yararlanılmış olmasını makale kabul ölçütleri arasında göstermesi gerektiğini vurgulamaktadir. Howard (2016) ve Ford, MacCallum ve Toit'in (1986) de önerdiği üzere dergilerin, AFA'nın raporlaştırılması için uyulması gereken kuralları içeren yönergeler veya şablonlar hazırlaması sorunları azaltacaktır. Bu kapsamda, çeşitli kaynaklar (Çokluk, Şekercioğlu, \& Büyüköztürk, 2014; Erkuş, 2016; Field, 2013; Ford ve diğ., 1986; Güngör, 2016; Howard, 2016; Pallant, 2007; Williams ve diğ., 2010) incelenerek hazırlanan ve Ek 1'de verilen kontrol listesinin araştırmacılara yararlı olacağı düşünülmektedir. 


\section{Summary}

Purpose and Significance: Latent variables generally become the subject of researches carried out in the fields of education and psychology. Since these variables are not available to be measured directly, a set of measures and actions shall be taken in order to ensure and increase their validity. Although we may encounter various definitions and classifications based on validity, it may be claimed that there is a consensus that construct validity shall particularly be studied with methods based on factor analysis. Exploratory factor analysis is a statistical technique, which aims to explain the measurement with limited number of factors by gathering the variables measuring the same construct or qualification. The researchers carrying out the exploratory factor analysis, shall evaluate plenty of conditions such as sample size, factor loadings, crossloading items, extracted variance ratio and number of items in a factor and shall make decisions with reference to these. Decision regarding the number of factors that will be extracted in this process is quite a significant decision.

Eigenvalue being greater than one (K1), scree plot, MAP test and parallel analysis results guide the researchers in deciding the number of factors. $\mathrm{K} 1$ criterion is criticized for producing a vast number of factors; and scree plot is criticized in connection with comprising subjectivity and not being consistent. We come across researches stating that more accurate results may be obtained with MAP test and parallel analysis when compared to the previous two and parallel analysis is superior to MAP test.

The accuracy of a research's findings is closely related with construct validity of the measurement tools, which are developed, adopted or used with the scope of the research. In other words, a part of the problems we may encounter depends on the determination of the tool used for the research. On the other hand, descriptive researches, which comprise of scale development and adaptation studies and reporting of these studies, reveal that there are some problems both in analysis and also in reporting process. The purpose of this study is to make a descriptive examination of the conditions that are taken into consideration during the exploratory analysis process of the scales taking part in Turkish Measurement Tools Index and to compare determined number of factor with parallel analysis results.

Methods: 500 of the scale reports taking part in Turkish Measurement Tools Index were selected with systematic sampling method in this research that is conducted with a descriptive approach. The number of the researches among the 500 whose full texts are reached and that includes exploratory factor analysis is 300. Information stated on the aforementioned research reports was examined over a form developed by the researchers. Descriptive statistics were calculated with the data stated on the research reports; 67 AFA report result, which specifies sample size, item number and eigenvalues completely, was compared with eigenvalues obtained with parallel analysis. Parallel analyses were carried out over 100 replications and means of eigenvalues were taken as a basis in the comparison.

Results: In consequence of the examinations, it was determined that information with regards to variables such as sample size, item number in measurement tool, admissible lowest factor load, explained variance ratio and number of factors was not present on 
some of the researches. It was observed within the studies where exploratory factor analyses were carried out that the calculated mean of the sample size is 404; the number of people per item is approximately 18 and dismissible lowest factor load is . 36 .

Although that not presenting any information regarding the number of factors decision making criterion is the most frequently met situation, it was determined that only $\mathrm{K} 1$ criterion was used in 79 studies $(26 \%)$ and $\mathrm{K} 1$ and scree plot were used together in 65 studies (22\%). The number of studies that utilized parallel analysis in number of factors decision making is three.

In cases where the factor number is more than one, it was determined that rotation was frequently carried out with varimax method. The number of studies where rotation is carried out by oblimin and promax methods is respectively 10 and nine. Furthermore, we encountered studies that do not mention extraction method, factor number decision making criterion or how the rotation is carried out. Moreover, although number of extraction was one in some studies, it was expressed that rotation was carried out by varimax.

It was determined that among the 67 analysis results that may be compared with parallel analysis results, there is over-extraction in 52 results and there is under-extraction in eight of them. The number of studies, which are supported with parallel analysis results, is seven.

Discussion and Conclusions: It was observed that principal component analysis, K1 criterion and varimax rotation are the most frequently encountered combinations. It was also determined that sufficient place was not given to the aspects, which shall be taken into consideration in exploratory factor analysis, on the research reports. It was detected that exploratory factor analysis was not utilized in some of the scale development studies. Therefore, there is no information with regards to factor construct of these scales. It may be expressed that such cases coincide with similar studies previously conducted. The point that where the condition we encountered differs from similar findings is that we found studies, which does not include the information of factor number. The facts that there is no scale adaptation in a study expressed to be a scale development study, that in a study expressed to have AFA, there is no regarding information nor finding and that in a study where it was expressed that .30 was taken as a basis for the lowest factor load, factor loads of all the items under a factor being below .30, indicate that there are significant problems in AFA operations and reports. In addition to this, while there is no information regarding how the rotation was carried out in 68 studies (28\%) where there is more than one extraction, the information stating that rotation was carried out by varimax method in six studies where a factor is decided attracts attention. When these problems are taken into consideration as a whole, a control list was suggested in contemplation of helping both to researchers and also arbitrators and consultants evaluating the related studies. 


\section{Kaynakça}

Acar Güvendir, M., \& Özer Özkan, Y. (2015). Türkiye'deki eğitim alanında yayımlanan bilimsel dergilerde ölçek geliştirme ve uyarlama konulu makalelerin incelenmesi. Elektronik Sosyal Bilimler Dergisi, 14(52), 23-33.

Akın, A. (2015). Psikolojide kullanılan güncel ölçme araçları: cilt I-II. Ankara: Nobel Yayın Dağıtım.

Amerikan Eğitim Araştırmaları Birliği Amerikan Psikoloji Birliği, Eğitim Ölçümleri Uluslararası Konseyi, (1998). Ĕgitimde ve psikolojide ölçme standartları. (Çev. S. Hovardaoğlu \& N. Sezgin). Ankara: Türk Psikologlar Derneği Yayınları, No: 14.

Anastasi, A., \& Urbina, S. (1997). Psychological testing ( $7^{\text {th }}$ ed). New Jersey: PrenticeHall, Inc.

Arrindell, W. A., \& Van der Ende, J.. (1985). An emprical test of the utility of the observations-to-variables ratio in factor and components analysis. Applied Psychological Measurement, 9(2), 165-178.

Bandalos, D. L., \& Finney, S. J. (2010). Factor analysis: Exploratory and confirmatory. In Gregory, R. Hancock \& Ralph. O. Mueller (Eds.). The reviewer's guide to quantitavi methods in the social sciences (pp. 93-114) New York: Routledge.

Baykul, Y. (2000). Eğitimde ve psikolojide ölçme: klasik test teorisi ve uygulamast. Ankara: ÖSYM Yayınları.

Bollen, K. A. (1989). Structural equations with latent variables. USA: John Wiley \& Sons, Inc.

Buja, A., \& Eyüboğlu, N. (1992). Remarks on parallel analysis. Multivariate Behavioral Research, 27(4), 509-540.

Büyüköztürk, Ş. (2018). Sosyal bilimler için veri analizi el kitabı: Ístatistik, araştırma deseni, SPSS uygulamalarl ve yorum (24. baskı). Ankara: Pegem Akademi.

Cassidy, S. (2016). The academic resilience scale (ARS-30): a new multidimensional construct measure. Frontiers in Psychology, 7(1787), 1-11.

Cattell, R. B. (1966). The scree test fort he number of factors. Multivariate Behavioral Research, 1(2), 245-276.

Comrey, A. L. (1978). Common methodological problems in factor analytic studies. Journal of Clinical and Consulting Psychology, 46(4), 648-659.

Comrey, A. L., \& Lee, H. B. (1992). A first course in factor analysis ( $2^{\text {nd }}$ ed). New Jersey: Lawrence Erlbaum Associates, Inc.

Costello, A. B., \& Osborne, J. (2005). Best practices in exploratory factor analysis: foru recommendatioans for getting the most from your analysis. Practical Assessment Research \& Evaluation, 10(7). Available online: http://pareonline.net/getvn.asp?v=10\&n=7

Crawford, A. V., Green, S. B., Levy, R., Lo, W, Scott, L., Svetina, D., \& Thompson, M. S. (2010). Evaluation of parallel analysis methods for determining the number of factors. Educational and Psychological Measurement, 70(6), 885-901.

Crawford, C. B., \& Koopman, P. (1973). A note on Horn's test fort he number of factors in factor analysis. Multivariate Behavioral Research, 8(1), 117-125. 
Crawford, C. B., \& Koopman, P. (1979). Note: Inter-rater reliability of scree test and mean square ratio test of number of factors. Perceptual and Motor Skills, 49, 223 226.

Crocker, L., \& Algina, J. (2008). Introduction to classical and modern test theory. USA: Cengage Learning.

Cronbach, L. J. (1990). Essentials of psychological testing $\left(5^{\text {th }}\right.$ ed). New York: Harpers Collins Publishers, Inc.

Cronbach, L. J., \& Meehl, P. E. (1955). Construct validity in psychological tests. Psychological Bulletin, 52(4), 281-302.

Çokluk, Ö., \& Koçak, D. (2016). Using Horn's parallel analysis method in exploratory factor analysis for determining the number of factors. Kuram ve Uygulamada Ë̌itim Bilimleri, 16(2), 537-551.

Çokluk, Ö., Şekercioğlu, G., \& Büyüköztürk, Ş. (2014). Sosyal bilimler için çok değişkenli istatistik: SPSS ve LISREL uygulamaları (3. baskı). Ankara: Pegem Akademi.

Çüm, S., \& Koç, N. (2013). Türkiye'de psikoloji ve eğitim bilimleri dergilerinde yayımlanan ölçek geliştirme ve uyarlama çalışmalarının incelenmesi. Ĕ̆itim Bilimleri ve Uygulama Dergisi, 12(24), 115-135.

Dancey, C. P., \& Reidy, J. (2007). Statistics without maths for psychology $\left(4^{\text {th }} \mathrm{ed}\right)$. Essex: Pearson Education Limited.

Delice, A., \& Ergene, Ö. (2015). Ölçek geliştirme ve uyarlama çalışmalarının incelenmesi: matematik eğitimi makaleleri örneği. Karaelmas Journal of Educational Sciences, 3, 60-75.

Ding, L., Velicer, W. F., \& Harlow, L. L. (1995). Effects of estimation methods, number of indicators per factor, and improper solutions on structural equation modeling fit indices. Structural Equation Modeling, 2(2), 119-144.

Erkuş, A. (2013). Davranış bilimleri için bilimsel araştırma süreci (4. baskı). Ankara: Seçkin Yayıncılık.

Erkuş, A. (2016). Psikolojide ölçme ve ölçek geliştirme - I: Temel kavramlar ve işlemler (3. baskı). Ankara: Pegem Akademi.

Fabrigar, L. R., Wegener, D. T., MacCallum, R. C., \& Strahan, E. J. (1999). Evaluating the use of exploratory factor analysis in psychological research. Psychological Bulletin, 4(3), 272-299.

Fava, J. L., \& Velicer, W. F. (1992). The effects of overextraction on factor and component analysis. Multivariate Behavioral Research, 27(3), 387-415.

Fava, J. L., \& Velicer, W. F. (1996). The effects of underextraction in factor and component analysis. Educational and Psychological Measurement, 56(6), 907-929.

Field, A. (2013). Discovering statistics using IBM SPSS statistics ( $4^{\text {th }}$ ed.). Canada: Sage.

Ford, J. K., MacCallum, R. C., \& Tait, M. (1986). The application of exploratory factor analysis in applied psychology: a critical review and analysis. Personnel Psychology, 39, 291-314. 
Franklin, S. B., Gibson, D. J., Robertson, P. A., Pohlmann, J. T., \& Fralish, J. S. (1995). Parallel analysis: a method for determining significant principal components. Journal of Vegetation Science, 6(1), 99-106.

Glorfeld, L. W. (1995). An improvement on Horn's parallel analysis methodology for selecting the correct number of factorsto retain. Educational and Psychological Measurement, 55(3), 377-393.

Gorsuch, R. L. (1983). Factor analysis ( $2^{\text {nd }}$ ed). New Jersey: Erlbaum.

Gorsuch, R. L. (2003). Factor analysis. In John A. Schinka \& Wayne F. Velicer (Eds.). Handbook of psychology, volume 2: research methods in psychology (pp. 143-164) New Jersey: John Wiley \& Sons, Inc.

Green, S. B., Levy, R., Thompson, M. S. Lu, M., \& Lo, W. (2012). A proposed solution to the problem with using completely random data to assess the number of factors with parallel analysis. Educational and Psycholoical Measurement, 72(3), 357-374.

Guadagnoli, E., \& Velicer, F. W. (1988). Relation of sample size to the stability of component patterns. Psychological Bulletin, 103(2), 265-275.

Guttman, L. (1954). Some necessary conditions for common-factor analysis. Psychometrika, 19(2), 149-161.

Güngör, D. (2016). Psikolojide ölçme araçlarının geliştirilmesi ve uyarlanması kılavuzu. Türk Psikoloji Yazılarl, 19(38), 104-112.

Hair, J. F., Black, W. C., Babin, B. J., Anderson, R. E., \& Tatham, R. L. (2006). Multivariate data analysis ( $6^{\text {th }}$ ed.). New Jersey: Pearson

Hayton, J. C., Allen, D. G., \& Scarpello, V. (2004). Factor retention decisions in exploratory factor analysis: a tutorial on parallel analysis. Organisational Research Methods, 7(2), 191-205.

Henson, R. K., \& Roberts, J. K. (2006). Use of exploratory factor analysis in published research: common errors and some comment on improved practice. Educational and Psychological Measurement, 66(3), 393-416.

Hinkin, T. R. (1998). A brief tutorial on the development of measuref for use in survey questionnaires. Organizational Research Methods, 2(1), 104-121.

Horn, J. L. (1965). A rationale and test fort he numbers of factors in factor analysis. Psychometrika, 30(2), 179-185.

Howard, M. C. (2016). A review of exploratory factor analysis decisions and overview of current practices: what we are doing and how can we improve? International Journal of Human-Computer Interaction, 32(1), 51-62.

Izquierdo, I., Olea, J., \& Abad, F. J. (2014). Exploratory factor analysis in validation studies: uses and recommendatitons. Psicothema, 26(3), 395-400.

Jolliffe, I. T. (1972). Discarding variables in a principal component analysis I: Artificial data. Journal of Royal Statistics Society, 21(2), 160-173.

Kaiser, H. F. (1960). The applications of electronic computers to factor analysis. Educational and Psychological Measurement, 20, 141-151.

Kane, M. T. (2001). Concerns in validity theory. Journal of Educational Measurement, $38(4), 319-342$. 
Karasar, N. (1998). Bilimsel araştırma yöntemi (17. baskı). Ankara: Nobel Yayın Dağıtım.

Kaya Uyanık, G., Güler, N., Taşdelen Teker, G., \& Demir, S. (2017). Türkiye'de eğitim alanında yayımlanan ölçek geliştirme çalışmalarının uygunluğunun çok yüzeyli Rasch modeli ile incelenmesi. Eğitimde ve Psikolojide Ölçme ve Değerlendirme Dergisi, 8(2), 183-199.

Kelecioğlu, H., \& Göçer Şahin, S. (2014). Geçmişten günümüze geçerlik. Eğitimde ve Psikolojide Ölçme ve Değerlendirme Dergisi, 5(2), 1-11.

Kline, P. (1994). An easy guide to factor analysis. New York: Routledge.

Kline, R. B. (2016) Principles and practice of structural equation modeling ( $\left.4^{\text {th }} \mathrm{ed}\right)$. New York: The Guilford Press.

Koçak, D., Çokluk, Ö., \& Kayri, M. (2016). Faktör sayısının belirlenmesinde MAP testi, paralel analiz, K1 ve yamaç birikinti grafiği yöntemlerinin karşılaştırılması. Yüzüncü Yıl Üniversitesi Eğitim Fakültesi Dergisi, 13(1), 330-359.

Kuzgun, F., \& Bacanlı, H. (2012). Rehberlik ve psikolojik danışmada kullanılan ölçme araçları ve programlar dizisi. Ankara: Nobel Yayın Dağıtım.

Lissitz, R. W., \& Samuelsen, K. (2007). A suggested change in terminology and emphasis regarding validity and education. Educational Researcher, 36(8), 437448.

Liu, O. L., \& Rijmen, F. (2008). A modified procedure for parallel analysis of ordered categorical data. Behavioral Research Methods, 40(2), 556-562.

Lorenzo-Seva, U., \& Ferrando, P. J. (2013). A comprehensive program for fitting exploratory and semiconfirmatory factor analysis and IRT models. Applied Psychological Measurement, 37(6), 497-498.

Loevinger, J. (1957). Objective tests as instruments of psychological theory. Psychological Reports, 3, 635-694.

Messick, S. (1995). Validity of psychological assessment: Validation of inferences from persons' responses and performances as scientific inquiry into score meaning. American Pschologist, 50(9), 741-749.

Muthen, L. K., \& Muthen, B. O. (2010). Mplus: statistical analysis with latent variables: user's guide Ver: 6.1. Los Angeles: Muthen\&Muthen.

Nunnally, J. C. (1978). Psychometric theory ( $2^{\text {nd }}$ ed). New York: McGraw-Hill.

O'Connor, B. P. (2000). SPSS and SAS programs for determining the number of components using parallel amalysis and Velicer's MAP test. Behavioral Research Methods, Instruments \& Computers, 32(3), 396-402.

Öner, N. (2006). Türkiye'de kullanılan psikolojik testlerden örnekler: bir başvuru kaynağı (2. baskı). İstanbul: Boğaziçi Üniversitesi Yayınevi.

Pallant, J. (2007). SPSS survival manual: A step by step guide to data analysis using the SPSS program ( $3^{\text {rd }}$ ed.). Berkshire: McGraw Hill.

Park, H. S., Dailey, R., \& Lemus, D. (2002). The use of exploratory factor analysis and principal component analysis in communication research. Human Communication Research, 28(4), 562-577. 
Patil, V. H., Singh, S. N., Mishra, S., \& Donavan, D. T. (2008). Efficient theory development and factor retention criteria: Abandon the "eigenvalue greater than one" criterion. Journal of Business Research, 61, 162-170.

Pearson, R., Mundfrom, D., \& Piccone, A. (2013). A comparison of ten methods for determining the number of factors in exploratory factor analysis. Multiple Linear Regresion Viewpoints, 39(1), 1-15.

Pedhazur, E. J., \& Schmelkin Pedhazur, L. (1991). Measurement, design, and analysis: an integrated approach. New Jersey: Lawrence Erlbaum Associates, Inc.

Peterson, R. A. (2000). A meta-analysis of variance accounted for and factor loadings in exploratory factor analysis. Marketing Letters, 11(3), 261-275.

Raiche, G., Walls, T. A., Magis, D., Riopel, M., \& Blais, J. (2013). Non-graphical solutions for Cattell's scree test. Methodology, 9(1), 23-29.

Ruscio, J., \& Roche, B. (2012). Determining the number of factors to retain in exploratory factor analysis usingcomparison data of known factor structure. Psychological Assessment, 24(2), 282-292.

Sireci, S. G. (2007). On validity theory and test validation. Educational Researcher, $36(8), 477-481$.

Stevens, J. P. (2009). Applied multivariate statistics for the social sciences $\left(5^{\text {th }}\right.$ ed.). New York: Routledge.

Şahin M. G., \& Boztunç Öztürk, N. (2018). Eğitim alanında ölçek geliştirme süreci: bir içerik analizi çalışması. Kastamonu Üniversitesi Kastamonu Eğitim Dergisi, 26(1), 191-199.

Tabachnick, B. G., \& Fidell, L. S. (2013). Using multivariate statistics $\left(6^{\text {th }}\right.$ ed.). New Jersey: Pearson.

Tavşancıl, E. (2002). Tutumların ölçülmesi ve SPSS ile veri analizi. Ankara: Nobel Yayın Dağıtım.

Thompson, B. (2004). Exploratory and confirmatory factor analysis: understandig concepts and applications. Washington: American Psychological Association.

Todman, J., \& Dugard, P. (2007). Approaching multivariate statistics: an introduction for psychology. New York: Psychology Press.

Uyar, S. (2012). Açımlayıcı faktör analizinde boyut sayısını belirlemede kullanılan yöntemlerin karşılaştırılması (Yayımlanmamış yüksek lisans tezi). Hacettepe Üniversitesi, Sosyal Bilimler Enstitüsü, Ankara.

Velicer, W. F. (1976). Determining the number of components from the matrix of partial correlations. Psychometrika, 41(3), 321-327.

Velicer, W. F., Eaton, C. A., \& Fava, J. L. (2000). Construct explication through factor or component analysis: a review and evaluation of alternative procedures for determining the number of factors or components. In Goffin, R. D. \& Helmes, E. (Eds.). Problems and solutions in human assessment: Honoring Douglas $N$. Jackson at seventy (pp. 41-71) Boston: Kluwer Academic/Plenum Publishers.

Watkins, M. W. (2000). Monte Carlo PCA for Parallel Analysis [computer software]. State College, PA: Ed \& Psych Associates. 
Williams, B., Brown, T., \& Onsman, A. (2010). Exploratory factor analysis: a five-step guide for novices. Journal of Emergency Primary Health Care, 8(3), 1-13.

Wood, J. M., Tataryn, D. J., \& Gorsuch, R. L. (1996). Effects of under- and overextraction on principal axis factor analysis with varimax rotation. Psychological Methods, 1(4), 354-365.

Wood, N. D., Akloubou Gnonhosou, D. C., \& Bowling, J. (2015). Combining parallel analysis and exploratory factor analysis in identifying relationship scales in secondary data. Marriage \& Family Rewiev, 51(5), 385-395.

Yavuz, G., \& Doğan, N. (2015). Boyut sayısı belirlemede Velicer'in map testi ve Horn'un paralel analizinin kullanılması. Hacettepe Üniversitesi Eğitim Fakültesi Dergisi, 30(3), 176-188.

Zwick, W. R., \& Velicer, W. F. (1982). Factors influencing four rules for determining the number of components to retain. Multivariate Behavioral Research, 17, 253269.

Zwick, W. R., \& Velicer, W. F. (1984). A comparison of five rules for determining the number of components in data sets. Paper presented at the Annual Meeting of the American Psychological Association (92 ${ }^{\text {nd }}$, Toronto, Ontario, August 24-28).

Zwick, W. R., \& Velicer, W. F. (1986). Comparison of five rules for determining the number of components to retain. Psychological Bulletin, 99(3), 432-442. 


\section{Ek 1.}

AFA'nın Raporlaştırılmasında Yararlanılabilecek Kontrol Listesi

Örneklem büyüklüğü

Madde sayıs1

KMO değeri ve Bartlett testi sonucu

Faktör çıkarma yöntemi

Kabul edilen en küçük faktör yükü

Binişiklik / çapraz yük için kabul edilen fark ya da oran

Özdeğerler

Faktör sayısına karar verme ölçütlerinin neler olduğu

Karar verilen faktör sayısı

Eksenlerin nasıl döndürüldüğü

Maddelerin tüm faktörlerdeki yükleri

Madde çıkarıldıysa sayısı ve gerekçeleri

Son durumda faktörlerde kaçar maddenin kaldığ

Faktörlerin her biri ve tümü için açıklanan varyans oranları

Faktörlerin etiketlenmesi / adlandırılması
Belirtildi

$\square$ Belirtildi

$\square$ Belirtildi

Belirtildi

Belirtildi

Belirtildi

Belirtildi

Belirtildi

Belirtildi

Belirtildi

Belirtildi

Belirtildi

Belirtildi

Belirtildi

Belirtildi 